\title{
Electrocatalytic oxidation of hydrazine on magnetic bar carbon paste electrode modified with benzothiazole and iron oxide nanoparticles: Simultaneous determination of hydrazine and phenol
}

\author{
Ali Benvidi*, Shahriar Jahanbani, Bibi-Fatemeh Mirjalili, Reza Zare \\ Chemistry Department, Yazd University, Yazd, Iran
}

\section{A R T I C L E I N F O}

Article history:

Received 6 November 2015

Accepted 16 January 2016

Published 5 April 2016

\section{Keywords:}

Modified electrode

Electerocatalytic oxidation

Hydrazine

Phenol

Magnetic bar modified carbon paste electrode

$\mathrm{Fe}_{3} \mathrm{O}_{4}$ nanoparticle

\begin{abstract}
A B S T R A C T
A magnetic bar carbon paste electrode (MBCPE) modified with $\mathrm{Fe}_{3} \mathrm{O}_{4}$ magnetic nanoparticles $\left(\mathrm{Fe}_{3} \mathrm{O}_{4} \mathrm{NPs}\right)$ and 2-(3,4-dihydroxyphenyl) benzothiazole (DPB) for the electrochemical determination of hydrazine was developed. The DPB was firstly self-assembled on the $\mathrm{Fe}_{3} \mathrm{O}_{4} \mathrm{NPs}$, and the resulting $\mathrm{Fe}_{3} \mathrm{O}_{4} \mathrm{NPs} / \mathrm{DPB}$ composite was then absorbed on the designed MBCPE. The MBCPE was used to attract the magnetic nanoparticles to the electrode surface. Owing to its high conductivity and large effective surface area, the novel electrode had a very large current response for the electrocatalytic oxidation of hydrazine. The modified electrode was characterized by voltammetry, scanning electron microscopy, electrochemical impedance spectroscopy, infrared spectroscopy, and UV-visible spectroscopy. Voltammetric methods were used to study the electrochemical behaviour of hydrazine on MBCPE $/ \mathrm{Fe}_{3} \mathrm{O}_{4} \mathrm{NPs} / \mathrm{DPB}$ in phosphate buffer solution $(\mathrm{pH}=7.0)$. The MBCPE/ $\mathrm{Fe}_{3} \mathrm{O}_{4} \mathrm{NPs} / \mathrm{DPB}$, acting as an electrochemical sensor, exhibited very high electrocatalytic activity for the oxidation of hydrazine. The presence of DPB was found to reduce the oxidation potential of hydrazine and increase the catalytic current. The dependence of the electrocatalytic current on the hydrazine concentration exhibited two linear ranges, $0.1-0.4 \mu \mathrm{mol} / \mathrm{L}$ and $0.7-12.0 \mu \mathrm{mol} / \mathrm{L}$, with a detection limit of $18.0 \mathrm{nmol} / \mathrm{L}$. Additionally, the simultaneous determination of hydrazine and phenol was investigated using the $\mathrm{MBCPE} / \mathrm{Fe}_{3} \mathrm{O}_{4} \mathrm{NPs} / \mathrm{DPB}$ electrode. Voltammetric experiments showed a linear range of $100-470 \mu \mathrm{mol} / \mathrm{L}$ and a detection limit of $24.3 \mu \mathrm{mol} / \mathrm{L}$ for phenol, and the proposed electrode was applied to the determination of hydrazine and phenol in water samples.
\end{abstract}

(C) 2016, Dalian Institute of Chemical Physics, Chinese Academy of Sciences.

Published by Elsevier B.V. All rights reserved.

\section{Introduction}

Although hydrazine is used in some fields, especially in industry, and plays an important role in human life, it is dangerous for the environment and hazardous to health [1,2]. Hydrazine is volatile, toxic and easily absorbed by oral, dermal, or inhalation routes [3]. Because of this, the measurement of hydrazine in the environment is important. Hydrazine can be measured using several methods, including spectrophotome- try, chemiluminescence, ion-exclusion chromatography, highperformance liquid chromatography, amperometry and voltammetry [4-11]. Electrochemical methods are very simple, sensitive, and effective for detecting different species. However, many species have high oxidation potential and low current on the surface of unmodified electrodes. Chemically modified electrodes increase the rate of electron transfer by reducing the overvoltage for the reaction $[12,13]$. The oxidation of hydrazine at carbon paste electrodes (CPE) has a high overpotential and

* Corresponding author. Tel: +98-353-8122645; Fax: +98-353-8210644; E-mail: abenvidi@yazd.ac.ir, benvidi89@gmail.com 
an extremely low oxidation current. Although the oxidation of hydrazine can be easily carried out on gold and platinum electrodes, these two metals are very expensive [14].

It is well known that phenol is highly dangerous to the skin, eyes, and mucous membranes in humans after short inhalation or dermal exposure, and is quite toxic via oral exposure. Prolonged exposure to phenol can have several serious effects on human health such as anorexia, progressive weight loss, diarrhea, vertigo, excessive salivation, darkening of the urine, and blood [15].Therefore, the detection of phenol and phenol derivatives is also very important. Phenol and phenol derivatives have been measured using various methods, including spectrophotometry, high-performance liquid chromatography, amperometry, enzyme sensing, and voltammetry [16-20]. Although, there are numerous reports on the individual determination of hydrazine and phenol using voltammetric methods, but few researchers have reported the simultaneous determination of hydrazine and phenol [21].

Great attention has been paid to the use of magnetic beads (MBs) in electrochemistry in recent years [22-24]. Magnetic nanoparticles are usually used owing to their super strong paramagnetic properties, low toxicity, and easy preparation. Iron oxide nanoparticles $\left(\mathrm{Fe}_{3} \mathrm{O}_{4} \mathrm{NPs}\right)$ are one of the most important components for fabricating magnetic beads possessing high surface area. Owing to their good properties, magnetic nanoparticles have been used to modify the surface of electrodes [25]. At the same time, $\mathrm{Fe}_{3} \mathrm{O}_{4}$ nanoparticles have been applied as catalysts in electrochemical methods because they increase the electrode surface area, electrical conductivity, and electron transfer kinetics for many species [26,27].

Self-assembly procedures are useful for modifying surfaces, and have been recently applied in various fields such as surface protection, molecular electronics, and fabrication of sensors and biosensors [28,29]. Self-assembled monolayers (SAM) are an elegant way to modify an electrode surface, and can be formed by spontaneous adsorption of self-assembling molecules on solid metals such as gold, silver, iron, nickel, and platinum [29-32]. Until now only a few studies have been reported on the self-assembly of $\mathrm{Fe}_{3} \mathrm{O}_{4} \mathrm{NPs}$ as a modification for the determination of chemical species. Herein, we report for the first time a novel electrochemical sensor for hydrazine determination based on self-assembled $\mathrm{Fe}_{3} \mathrm{O}_{4} \mathrm{NPs}$ as modifier and carbon paste electrode as the platform.

The exploitation of electrocatalytic processes at the surface of modified electrodes has been investigated to increase the oxidation current and minimize the oxidation overvoltage of target species. In our previous work in electrocatalysis, a modified electrode (MBCPE/DPSPP/RGO/Fe $\mathrm{O}_{4} \mathrm{NPs}$ ) was designed for the determination of hydrazine and simultaneous determination of hydrazine and hydroxylamine [33]. In this work, 2-(3,4-dihydroxyphenyl) benzothiazole (DPB), an organo-sulfur compound, was used as a modifier. The main aim was to achieve electrocatalytic oxidation of hydrazine and simultaneous determination of hydrazine and phenol using a self-assembling modifier (DPB) applied to the surface of $\mathrm{Fe}_{3} \mathrm{O}_{4}$ nanoparticles. Firstly, a magnet bar carbon paste electrode (MBCPE) was fabricated [34] and $\mathrm{Fe}_{3} \mathrm{O}_{4} \mathrm{NPs} / \mathrm{DPB}$ was adsorbed onto the electrode surface to prepare a MBCPE/ $\mathrm{Fe}_{3} \mathrm{O}_{4} \mathrm{NPs} / \mathrm{DPB}$ electrochemical sensor. A schematic representation of the MBCPE/Fe $3 \mathrm{O}_{4} \mathrm{NPs} / \mathrm{DPB}$ based electrochemical hydrazine sensor is shown in Scheme 1. As mentioned above, the magnetic bar was inserted into the CPE to attract the magnetic material to the electrode surface, a method that can lead to a great enhancement of effective surface area with a good stability and without any loss of magnetic nanoparticles from the electrode surface during electrochemical tests. The obtained results revealed that the anodic peak current for the $\mathrm{MBCPE} / \mathrm{Fe}_{3} \mathrm{O}_{4} \mathrm{NPs} /$ DPB sensor was proportional to the hydrazine concentration in two ranges (0.1-0.4 and $0.7-12.0 \mu \mathrm{mol} / \mathrm{L})$, and the obtained detection limit was $18.0 \mathrm{nmol} / \mathrm{L}$. Under optimum conditions, some kinetic parameters for hydrazine oxidation, such as the diffusion coefficient and electron transfer coefficient, were determined using electrochemical methods.

The oxidation potentials of hydrazine and phenol on a bare carbon paste electrode are close to each other and their differential pulse voltammograms (DPV) overlap. The DPV of a mixture of these analytes at the proposed electrode (MBCPE/ $\mathrm{Fe}_{3} \mathrm{O}_{4} \mathrm{NPs} / \mathrm{DPB}$ ) showed a peak potential difference (380.0 $\mathrm{mV}$ ). This is sufficient to perform simultaneous determination of hydrazine and phenol, as conducted in this research. Additionally, the fabricated electrochemical sensor (MBCPE/ $\mathrm{Fe}_{3} \mathrm{O}_{4} \mathrm{NPs} / \mathrm{DBP}$ ) was applied to the determination of hydrazine in tablet samples, and the simultaneous determination of hydrazine and phenol in water samples.

\section{Experimental}

\subsection{Chemicals and apparatus}

The DPB was synthesized according to a previously reported method [35]. The chemical structure of DPB is shown in the Scheme 1. Other materials and chemicals were purchased from Merck and used as received. The electrochemical measurements were performed with an Autolab potentiostat/galvanostat (PGSTAT-302 N, Eco Chemie, Netherlands). The experimental conditions were controlled with Nova 1.7 software on a PC. The working, counter, and reference electrodes were the magnetic bar carbon paste $/ \mathrm{Fe}_{3} \mathrm{O}_{4} \mathrm{NPs} / \mathrm{DPB}$ electrode, a platinum electrode, and an $\mathrm{Ag} / \mathrm{AgCl}$ (sat.), $\mathrm{KCl}$ (3 mol/L) electrode, respectively. All potentials in this research are reported

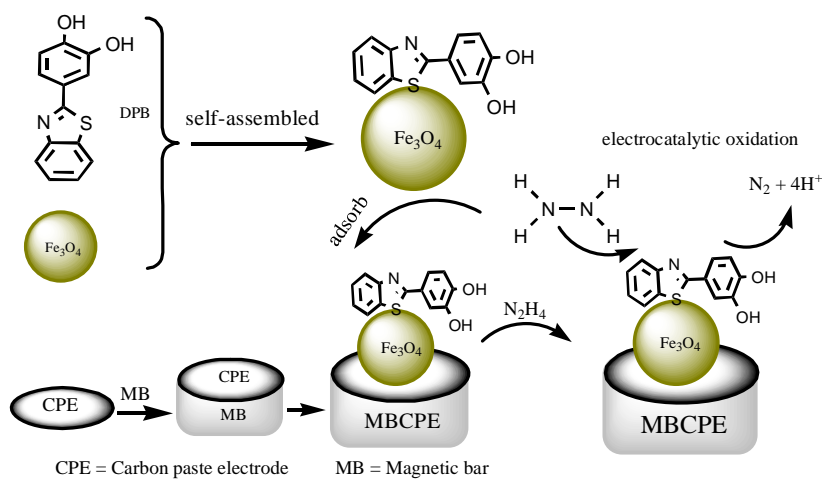

Scheme 1. Schematic representation of the electrochemical detection of hydrazine based on the MBCPE/ $\mathrm{Fe}_{3} \mathrm{O}_{4} \mathrm{NPs} / \mathrm{DPB}$ electrode. 
with respect to this reference electrode. Metrohm model 691 $\mathrm{pH} / \mathrm{mV}$ meters were used for $\mathrm{pH}$ measurements. FT-IR experiments were performed using a spectrometer (VERTEX 70, Bruker Optics, Ettlingen, Germany) equipped with a deuterated triglycine sulfate (DTGS) detector. Scanning electron microscopy (SEM) was performed with a TESCAN VEGA3 instrument. The absorption spectra of the samples were obtained using an Analytik Jena SPECORD-205 spectrophotometer in the range of 190-1000 $\mathrm{nm}$ and at $1 \mathrm{~nm}$ resolution.

\subsection{Synthesis of $\mathrm{Fe}_{3} \mathrm{O}_{4} \mathrm{NPS}$}

$\mathrm{Fe}_{3} \mathrm{O}_{4}$ nanoparticles were synthesized in accordance with the method described in Ref. [36]. Briefly, $5.17 \mathrm{~g} \mathrm{FeCl}_{3}$ and 2.02 g $\mathrm{FeSO}_{4} \cdot 7 \mathrm{H}_{2} \mathrm{O}$ were dissolved in $1 \mathrm{~L}$ deionized water under ultrasonication. Subsequently, a $\mathrm{NaOH}$ solution (1 mol/L) was added dropwise into the mixture over 50 min under ultrasonication and nitrogen atmosphere, using a burette. The colour of the resulting mixture changed from yellow to black [36]. The formed precipitate was collected with a permanent magnet and washed five times with distilled water.

\subsection{Preparation of the electrode}

Carbon paste was prepared by hand mixing $0.5 \mathrm{~g}$ graphite powder and three drops of paraffin (Dc 350, Merck) using a mortar and pestle. This paste was then packed into the end of a glass tube (ca. $6 \mathrm{~mm}$ i.d. and $10 \mathrm{~cm}$ long). A magnetic bar was inserted into the tube to be coated with the carbon paste to provide a magnetic field. An electrical contact was made by pushing a conductive copper wire through the glass tube to connect with the magnetic bar [34]. For the attraction of $\mathrm{Fe}_{3} \mathrm{O}_{4} \mathrm{NPs} / \mathrm{DPB}$ onto the MBCPE electrode surface, a dispersion of $\mathrm{Fe}_{3} \mathrm{O}_{4} \mathrm{NPs} / \mathrm{DPB}(1 \mathrm{mg} / \mathrm{mL}$ ) was dropped onto the MBCPE electrode. After washing the electrode surface with deionized water, the fabrication of the electrochemical sensor (MBCPE/ $\mathrm{Fe}_{3} \mathrm{O}_{4} \mathrm{NPs} / \mathrm{DPB}$ ) was complete.

\section{Results and discussion}

\subsection{Modification of the $\mathrm{Fe}_{3} \mathrm{O}_{4} \mathrm{NPS}$ by $\mathrm{DPB}$}

A self-assembled monolayer of DPB was formed on the $\mathrm{Fe}_{3} \mathrm{O}_{4}$ nanoparticles by mixing $5 \mathrm{mmol}$ DPB and $1 \mathrm{mg} \mathrm{Fe} \mathrm{O}_{4} \mathrm{NPs}$ in $1 \mathrm{~mL}$ ethanol solution for $5 \mathrm{~h}$ at room temperature. The mixture was placed onto the magnet bar electrode and then rinsed several times with distilled water until all unadsorbed modifier had been washed away. The FT-IR spectrum of the $\mathrm{Fe}_{3} \mathrm{O}_{4} \mathrm{NPs}$ (Fig. 1(a), curve (1)) showed a weak peak at 3500-3300 $\mathrm{cm}^{-1}$, corresponding to the $\mathrm{O}-\mathrm{H}$ stretch of water molecules accompanying the $\mathrm{Fe}_{3} \mathrm{O}_{4} \mathrm{NPs}$ [37]. Also shown in Fig. 1(a) curve (2), the FT-IR spectrum of DPB exhibited $v=3478(\mathrm{OH}), 1623$ $(\mathrm{C}=\mathrm{N}), 1589$ and 1470 (C=C, aromatic), 1364, 1264 (C=S), 1200 (C-0), 1175, 1071, 1055, 765, $721(=\mathrm{C}-\mathrm{H}) \mathrm{cm}^{-1}$ [35]. The FT-IR spectrum of $\mathrm{Fe}_{3} \mathrm{O}_{4} \mathrm{NPs} / \mathrm{DPB}$ (curve (3)) was similar to that of DPB, demonstrating that DPB molecules were successfully adsorbed on the nanoparticles. All of the DPB FT-IR peaks were
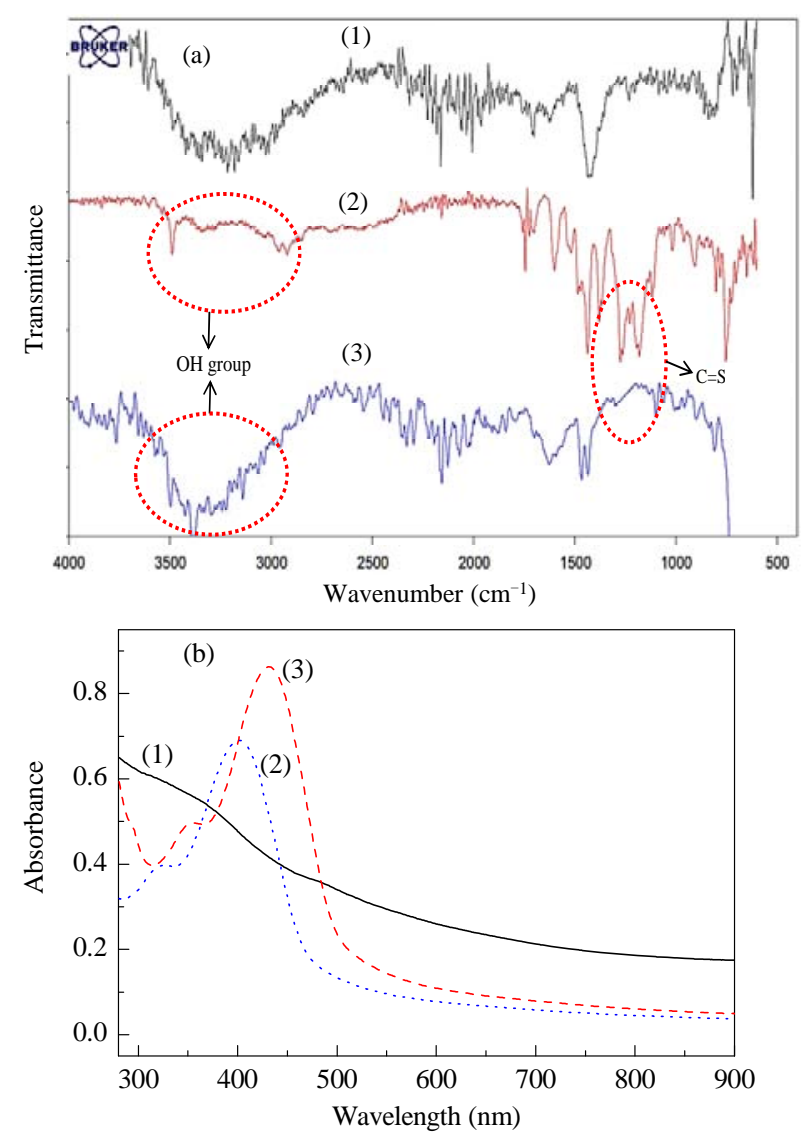

Fig. 1. (a) FT-IR spectra and (b) UV-Vis spectra of (1) $\mathrm{Fe}_{3} \mathrm{O}_{4} \mathrm{NPs}$, (2) DPB and (3) $\mathrm{Fe}_{3} \mathrm{O}_{4} \mathrm{NPs} / \mathrm{DPB}$.

seen in the $\mathrm{Fe}_{3} \mathrm{O}_{4} \mathrm{NPs} / \mathrm{DPB}$ spectrum except $v=1264$ ( $\mathrm{C}=\mathrm{S}$ ) $\mathrm{cm}^{-1}$, which indicated that the DPB molecules were connected to the $\mathrm{Fe}_{3} \mathrm{O}_{4} \mathrm{NPs}$ via the benzothiazole group. A peak $(\mathrm{O}-\mathrm{H}, v=$ $3300 \mathrm{~cm}^{-1}$ ) indicating the presence of free $\mathrm{OH}$ groups was also observed, meaning that the hydroxyl groups of DPB in $\mathrm{Fe}_{3} \mathrm{O}_{4} \mathrm{NPs} / \mathrm{DPB}$ were free for an electrocatalytic role.

Fig. 1(b) reveals the UV-Vis absorbance spectra of the bare $\mathrm{Fe}_{3} \mathrm{O}_{4} \mathrm{NPs}$, DPB, and $\mathrm{Fe}_{3} \mathrm{O}_{4} \mathrm{NPs}$ with self-assembled DPB. The $\mathrm{Fe}_{3} \mathrm{O}_{4} \mathrm{NPs}$ displayed a weak absorption band at $300 \mathrm{~nm}$ (curve (1) [38]. DPB displayed an absorption band at $360 \mathrm{~nm}$ (curve (2)) [39], while a sharp peak at $420 \mathrm{~nm}$ was observed in the spectrum of $\mathrm{Fe}_{3} \mathrm{O}_{4} \mathrm{NPs} / \mathrm{DPB}$ which was related to presence of DPB on the $\mathrm{Fe}_{3} \mathrm{O}_{4} \mathrm{NPs}$ surface. Moreover, the red shift of the spectrum confirmed that the DPB molecules were self-assembled on the $\mathrm{Fe}_{3} \mathrm{O}_{4} \mathrm{NPs}$.

\subsection{Characterization of the electrode surface}

The surface of the MBCPE/ $\mathrm{Fe}_{3} \mathrm{O}_{4} \mathrm{NPs} / \mathrm{DPB}$ electrode was studied by SEM, cyclic voltammetry, and electrochemical impedance spectroscopy. The morphology of bare MBCPE, $\mathrm{MBCPE} / \mathrm{Fe}_{3} \mathrm{O}_{4} \mathrm{NPs}$ and $\mathrm{MBCPE} / \mathrm{Fe}_{3} \mathrm{O}_{4} \mathrm{NPs} / \mathrm{DPB}$ was studied by SEM (Fig. 2). As shown in Fig. 2(a), the bare MBCPE had an amorphous and flat structure. Fig. 2(b) shows that the $\mathrm{Fe}_{3} \mathrm{O}_{4} \mathrm{NPs}$-modified electrode had a higher surface area than the bare electrode because of the large amount of spherical 

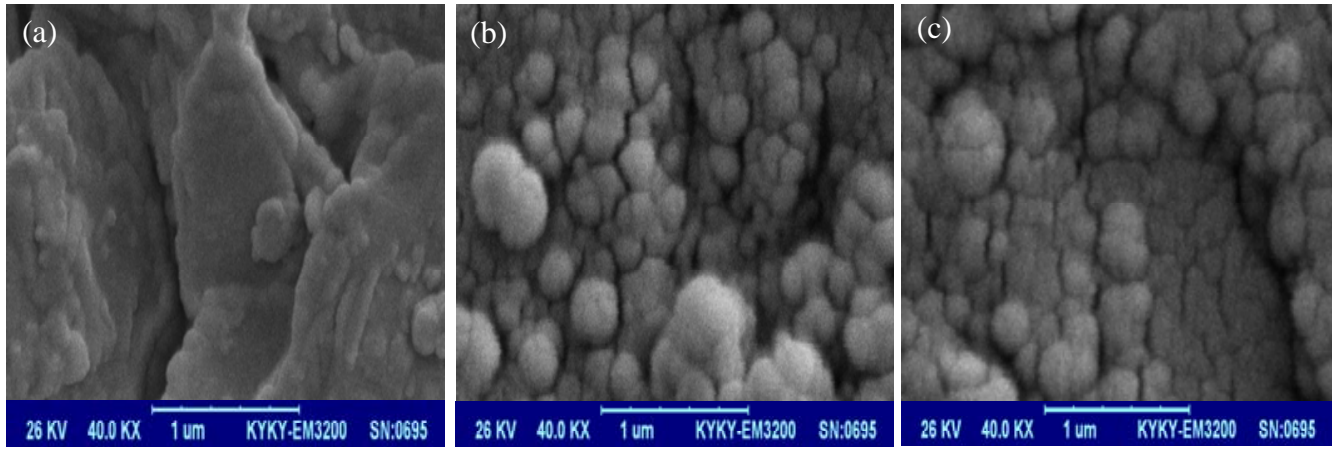

Fig. 2. SEM images of (a) MBCPE, (b) MBCPE/ $/ \mathrm{Fe}_{3} \mathrm{O}_{4} \mathrm{NPs}$, and (c) MBCPE $/ \mathrm{Fe}_{3} \mathrm{O}_{4} \mathrm{NPs} / \mathrm{DPB}$ electrodes.

shapes on its surface. Fig. 2 (c) reveals that the $\mathrm{Fe}_{3} \mathrm{O}_{4} \mathrm{NPs} / \mathrm{DPB}$ surface was not rougher than that of the $\mathrm{Fe}_{3} \mathrm{O}_{4} \mathrm{NPs}$. In addition, the conjoined spherical-like shapes observable in Fig. 2(c) are probably indicative of the self-assembly of the DPB molecules on the surface of the $\mathrm{Fe}_{3} \mathrm{O}_{4} \mathrm{NPs}$.

The surface of different electrodes was investigated by cyclic voltammetry in a solution containing the redox couple $\mathrm{K}_{4} \mathrm{Fe}(\mathrm{CN})_{6}(0.5 \mathrm{mmol} / \mathrm{L}) / \mathrm{K}_{3} \mathrm{Fe}(\mathrm{CN})_{6}(0.5 \mathrm{mmol} / \mathrm{L})$ and $\mathrm{KCl}(0.1$ $\mathrm{mol} / \mathrm{L})$. Fig. 3(a) shows the cyclic voltammograms of the three prepared electrodes, MBCPE, MBCPE/Fe $\mathrm{F}_{4} \mathrm{NPs}$, and $\mathrm{MBCPE} / \mathrm{Fe}_{3} \mathrm{O}_{4} \mathrm{NPs} / \mathrm{DPB}$ in the solution. Curve (1) in Fig. 3(a) reveals the peak current oxidation of $\left[\mathrm{Fe}(\mathrm{CN})_{6}\right]^{3-/ 4-}$ at the bare MBCPE. Placing $\mathrm{Fe}_{3} \mathrm{O}_{4} \mathrm{NPs}$ on the surface of the electrode (curve (2)) led to an increase in the peak current of the $\left[\mathrm{Fe}(\mathrm{CN})_{6}\right]^{3-/ 4-}$ redox couple, owing to the greatly increased electrode surface area. After adsorption of DPB on the MBCPE/ $\mathrm{Fe}_{3} \mathrm{O}_{4} \mathrm{NPs}$ electrode surface (curve (3)), the $\left[\mathrm{Fe}(\mathrm{CN})_{6}\right]^{3-/ 4-}$ peak current decreased owing to reductions in the effective area and number of active sites for electron transfer. The surface area of the $\mathrm{MBCPE} / \mathrm{Fe}_{3} \mathrm{O}_{4} \mathrm{NPs}$ electrode was estimated to be $0.52 \mathrm{~cm}^{2}$ from cyclic voltammograms of $\mathrm{K}_{3}\left[\mathrm{Fe}(\mathrm{CN})_{6}\right](1.0 \mathrm{mmol} / \mathrm{L})$ at various scan rates using the Randles-Sevcik equation [40].
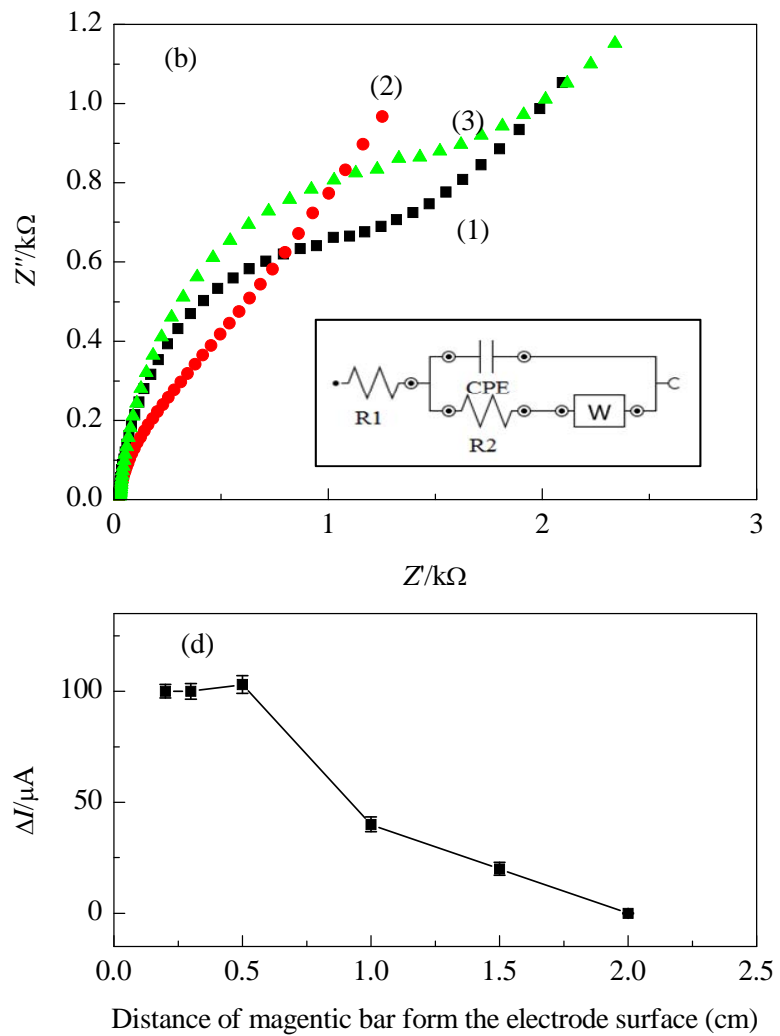

Fig. 3. (a) Cyclic voltammograms of (1) MBCPE, (2) MBCPE/ $\mathrm{Fe}_{3} \mathrm{O}_{4} \mathrm{NPs}$, and (3) MBCPE/ $\mathrm{Fe}_{3} \mathrm{O}_{4} \mathrm{NPs} / \mathrm{DPB}$ electrode in $\mathrm{KCl}$ solution (0.1 mol/L) containing the redox couples of $\mathrm{K}_{4} \mathrm{Fe}(\mathrm{CN})_{6}(0.5 \mathrm{mmol} / \mathrm{L})$ and $\mathrm{K}_{3} \mathrm{Fe}(\mathrm{CN})_{6}(0.5 \mathrm{mmol} / \mathrm{L})$, scan rate $100 \mathrm{mV} / \mathrm{s}$. (b) Nyquist plots of (1) MBCPE, (2) $\mathrm{MBCPE} / \mathrm{Fe}_{3} \mathrm{O}_{4} \mathrm{NPs}$, and (3) MBCPE/ $\mathrm{Fe}_{3} \mathrm{O}_{4} \mathrm{NPs} / \mathrm{DPB}$. EIS conditions: ac potential amplitude of $5 \mathrm{mV}$, frequency range of $10 \mathrm{kHz}$ to $0.1 \mathrm{~Hz}$. Inset: The applied equivalent circuit to model impedance data in the presence of redox couples $\left[\mathrm{Fe}(\mathrm{CN})_{6}\right]^{3-/ 4-}$. (c) Variation of anodic peak current versus concentration of $\mathrm{Fe}_{3} \mathrm{O}_{4} \mathrm{NPs}$ in $\mathrm{KCl}$ solution $(0.1 \mathrm{~mol} / \mathrm{L})$ containing the redox couples of $\mathrm{K}_{4} \mathrm{Fe}(\mathrm{CN})_{6}(0.5 \mathrm{mmol} / \mathrm{L})$ and $\mathrm{K}_{3} \mathrm{Fe}(\mathrm{CN})_{6}(0.5 \mathrm{mmol} / \mathrm{L})$. (d) Variation of anodic peak current versus distance of magnetic bar of electrode surface in $\mathrm{KCl}$ solution $(0.1 \mathrm{~mol} / \mathrm{L})$ containing the redox couples of $\mathrm{K}_{4} \mathrm{Fe}(\mathrm{CN})_{6}$ $(0.5 \mathrm{mmol} / \mathrm{L})$ and $\mathrm{K}_{3} \mathrm{Fe}(\mathrm{CN})_{6}(0.5 \mathrm{mmol} / \mathrm{L})$. 
The electrode fabrication process was also characterized by EIS. Fig. 3(b) shows a comparison of the EIS signals of the $\mathrm{MBCPE}, \mathrm{MBCPE} / \mathrm{Fe}_{3} \mathrm{O}_{4} \mathrm{NPs}$, and $\mathrm{MBCPE} / \mathrm{Fe}_{3} \mathrm{O}_{4} \mathrm{NPs} / \mathrm{DPB}$ electrodes in $\mathrm{KCl}$ solution $(0.1 \mathrm{~mol} / \mathrm{L})$ containing the $\left[\mathrm{Fe}(\mathrm{CN})_{6}\right]^{3-/ 4-}$ redox couple. The charge transfer resistance of the bare MBCPE was $R_{\mathrm{ct}}=1.64 \mathrm{k} \Omega$. When the $\mathrm{Fe}_{3} \mathrm{O}_{4}$ nanoparticles were added to the surface of the electrode the conductance surface increased, which decreased its charge transfer resistance $\left(R_{\mathrm{ct}}=0.42 \mathrm{k} \Omega\right.$; curve (2)). In contrast, when the electrode surface was covered by DPB, its electron transfer resistance increased $\left(R_{\mathrm{ct}}=1.76 \mathrm{k} \Omega\right.$, curve (3)). Thus, there was a good agreement between the results of the CV and EIS characterizations of the electrode fabrication. The inset of Fig. 3(b) shows the Randles equivalent circuit applied for analyzing the Nyquist plots. In this equivalent circuit, R1 is the electrolyte resistance (for $\left[\mathrm{Fe}(\mathrm{CN})_{6}\right]^{3-/ 4-}(0.5$ $\mathrm{mmol} / \mathrm{L})$ and $\mathrm{KCl}(0.1 \mathrm{~mol} / \mathrm{L})), \mathrm{W}$ is the Warburg impedance resulting from the diffusion of ions, CPE is the constant phase element, and $\mathrm{R} 2\left(R_{\mathrm{ct}}\right)$ is the electron transfer resistance.

The optimization of the concentration of $\mathrm{Fe}_{3} \mathrm{O}_{4} \mathrm{NPs}$ suspension applied to the electrode surface was performed (Fig. 3(c)). As shown in Fig. 3(c), $\Delta I\left(\Delta I=I_{\text {final }}-I_{\text {initial, }}\right.$ where $I_{\text {final }}$ and $I_{\text {initial }}$ are the $\left[\mathrm{Fe}(\mathrm{CN})_{6}\right]^{3-/ 4-}$ peak current in the presence and absence of $\mathrm{Fe}_{3} \mathrm{O}_{4} \mathrm{NPs}$ on the surface of the MBCPE, respectively, in 0.1 $\mathrm{mol} / \mathrm{L} \mathrm{KCl}$ ) was enhanced by increasing the concentration of the $\mathrm{Fe}_{3} \mathrm{O}_{4} \mathrm{NPs}$ suspension from 0.2 to $1.0 \mathrm{mg} / \mathrm{mL}$, beyond which it leveled off. These results indicated that increasing the concentration of the $\mathrm{Fe}_{3} \mathrm{O}_{4} \mathrm{NPs}$ suspension to $1.0 \mathrm{mg} / \mathrm{mL}$ allowed the total surface of the MBCPE electrode to become saturated with the NPs, and that increases beyond this value this had no effective influence on the surface of the designed electrode. According to these observations, $1.0 \mathrm{mg} / \mathrm{mL}$ was chosen as the optimum concentration of $\mathrm{Fe}_{3} \mathrm{O}_{4} \mathrm{NPs}$ for application to the electrode surface.

Another parameter which must be optimized in this work is the distance of the magnet bar from the surface of the prepared electrode, because of its significant effect on the attraction of the magnetic nanoparticles onto the surface of electrode. As Fig. 3(d) indicates, with increasing distance of the magnetic bar from the electrode surface (from 0.2 to $0.5 \mathrm{~cm}), \Delta I\left(\Delta I=I_{\mathrm{MBCPE}}-\right.$ $I_{\mathrm{CPE}}$, where $I_{\mathrm{MBCPE}}$ and $I_{\mathrm{CPE}}$ are the peak current measured at $\mathrm{CPE}$ and MBCPE, respectively, in a solution containing $\left[\mathrm{Fe}(\mathrm{CN})_{6}\right]^{3-/ 4-}$ $(0.5 \mathrm{mmol} / \mathrm{L})$ and $\mathrm{KCl}(0.1 \mathrm{~mol} / \mathrm{L}))$ was approximately constant until a certain point, and then decreased. This result can be explained by a decreasing amount of $\mathrm{Fe}_{3} \mathrm{O}_{4} \mathrm{NPs}$ attracted to the electrode surface when the distance was increased to more than $0.5 \mathrm{~cm}$, so $0.5 \mathrm{~cm}$ was selected as the optimum distance of the magnetic bar from the electrode surface.

\subsection{Electrocatalysis of hydrazine oxidation}

Cyclic voltammetry was used to evaluate the electrocatalytic oxidation of hydrazine in the presence of the DPB modifier. The electrochemical parameters of DPB are reported in Ref. [35]. Cyclic voltammograms were recorded at the MBCPE, $\mathrm{MBCPE} / \mathrm{Fe}_{3} \mathrm{O}_{4} \mathrm{NPs}$, and MBCPE/ $\mathrm{Fe}_{3} \mathrm{O}_{4} \mathrm{NPs} / \mathrm{DPB}$ electrodes in a phosphate buffer solution $(\mathrm{pH}=7.0)$. The typical processes associated with the electrochemical oxidation of hydrazine are

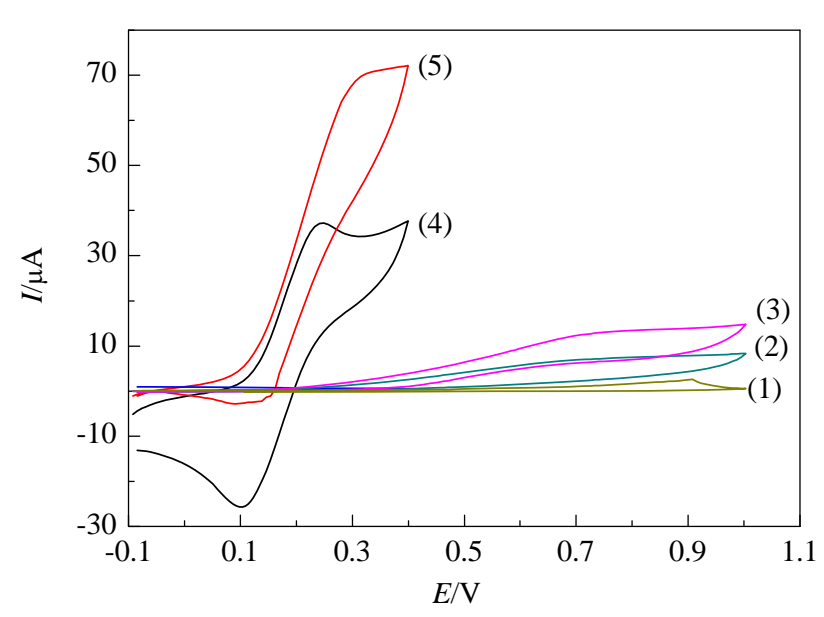

Fig. 4. Cyclic voltammograms of phosphate buffer solution $(0.1 \mathrm{~mol} / \mathrm{L}$; $\mathrm{pH}=7.0$ ) at scan rate $20 \mathrm{mV} / \mathrm{s}$. (1) MBCPE in absence of hydrazine; (2) $\mathrm{MBCPE}$ in presence of hydrazine $(10 \mu \mathrm{mol} / \mathrm{L})$; (3) MBCPE/ $/ \mathrm{Fe}_{3} \mathrm{O}_{4} \mathrm{NPs}$ in presence of hydrazine; (4) MBCPE/ $\mathrm{Fe}_{3} \mathrm{O}_{4} \mathrm{NPs} / \mathrm{DPB}$ in absence of hydrazine; (5) MBCPE $/ \mathrm{Fe}_{3} \mathrm{O}_{4} \mathrm{NPs} / \mathrm{DPB}$ in present of hydrazine.

illustrated in Fig. 4. Curves (1) and (2) in Fig. 4 show cyclic voltammograms of a phosphate buffer solution $(0.1 \mathrm{~mol} / \mathrm{L} ; \mathrm{pH}$ $=7.0$ ) at the MBCPE in the absence and presence of hydrazine (10 $\mu \mathrm{mol} / \mathrm{L})$, respectively. Curve (3) shows the cyclic voltammogram at $\mathrm{MBCPE} / \mathrm{Fe}_{3} \mathrm{O}_{4} \mathrm{NPs}$ in presence of hydrazine. Curves (4) and (5) exhibit the cyclic voltammograms at MBCPE/ $\mathrm{Fe}_{3} \mathrm{O}_{4} \mathrm{NPs} / \mathrm{DPB}$ in the absence and presence of hydrazine, respectively. Comparison of curves (1) and (2) reveals that hydrazine was oxidized at $0.70 \mathrm{~V}$ on the MBCPE electrode in the absence of modifier. The oxidation current of hydrazine was enhanced in the presence of $\mathrm{Fe}_{3} \mathrm{O}_{4}$ nanoparticles. In the presence of $\mathrm{DPB}$, the hydrazine was oxidized at $0.15 \mathrm{~V}$; a potential about $550 \mathrm{mV}$ more negative than that observed in absence of DPB. As this figure shows, hydrazine was more easily oxidized in the presence of DPB, and the current at $\mathrm{MBCPE} / \mathrm{Fe}_{3} \mathrm{O}_{4} \mathrm{NPs} /$ DPB was enhanced by almost two times in the presence of hydrazine. These results confirm that electrocatalytic behavior was obtained for the oxidation of hydrazine in the presence of DPB as a heterogeneous modifier on the surface of MBCPE/ $\mathrm{Fe}_{3} \mathrm{O}_{4} \mathrm{NPs}$.

\subsection{Influence of specific variables}

The influence of variables including $\mathrm{pH}$, DPB concentration, and time for self-assembly was studied. As previously explained, a self-assembled monolayer of DPB was formed on the $\mathrm{Fe}_{3} \mathrm{O}_{4}$ nanoparticles when different amounts of DPB and $1.0 \mathrm{mg}$ of $\mathrm{Fe}_{3} \mathrm{O}_{4} \mathrm{NPs}$ were mixed in $1.0 \mathrm{~mL}$ ethanol solution for $5 \mathrm{~h}$ at room temperature. The influence of the concentration of DPB in the $\mathrm{Fe}_{3} \mathrm{O}_{4} \mathrm{NP}$ suspension $(1.0 \mathrm{mg} / \mathrm{mL})$ on the oxidation peak current of hydrazine was studied for mass ratios of $1: 1$ to $7: 1$ for $\mathrm{DPB} / \mathrm{Fe}_{3} \mathrm{O}_{4} \mathrm{NPs}$ at a scan rate of $20 \mathrm{mV} / \mathrm{s}$. This experiment was carried out for three different concentrations of hydrazine $(0.1,0.2$, and $0.3 \mu \mathrm{mol} / \mathrm{L})$. The results showed that increasing the concentration of DPB in the $\mathrm{Fe}_{3} \mathrm{O}_{4} \mathrm{NPs}$ suspension up to a mass ratio of 3:1 increased the measured peak current. Further 

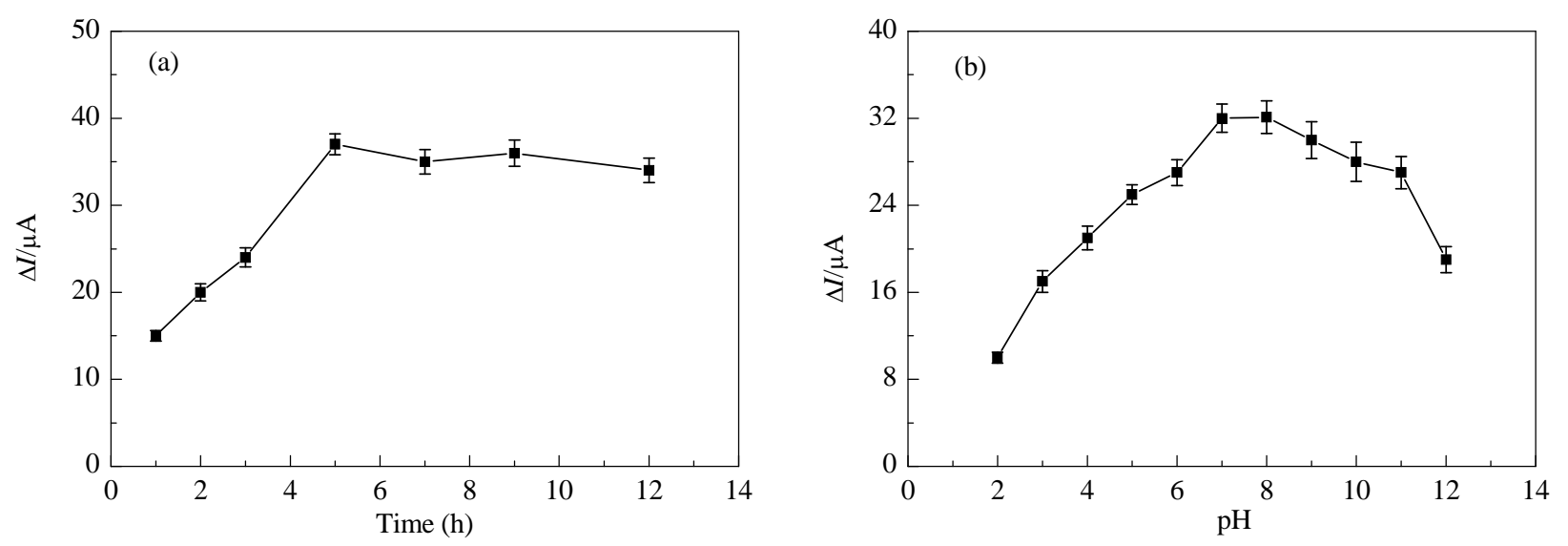

Fig. 5. (a) Variation of anodic peak current of DPB versus time of self-assembles in phosphate buffer solution (pH = 7.0); (b) Variation of anodic peak current of DPB versus $\mathrm{pH}$ in presence of hydrazine at phosphate buffer solution.

increases in the ratio of DPB had no effect on the magnitude of the hydrazine peak current. This result revealed that the total surface of the $\mathrm{Fe}_{3} \mathrm{O}_{4} \mathrm{NPs}$ was saturated with DPB at a DPB/ $\mathrm{Fe}_{3} \mathrm{O}_{4} \mathrm{NPs}$ mass ratio of $3: 1$. Therefore, mass ratio of $3: 1$ for DPB: $\mathrm{Fe}_{3} \mathrm{O}_{4} \mathrm{NPs}$ was selected as the optimal mass ratio.

The optimum time for the self-assembly of DPB on the $\mathrm{Fe}_{3} \mathrm{O}_{4} \mathrm{NPs}$ was also examined. As shown in Fig. 5(a), as the time allowed for the self-assembly of DPB on the $\mathrm{Fe}_{3} \mathrm{O}_{4} \mathrm{NPs}$ was increased up to $5 \mathrm{~h}, \Delta I\left(\Delta I=I_{\text {final }}-I_{\text {initial, }}\right.$ where $I_{\text {final }}$ and $I_{\text {initial }}$ are the DPB peak current with and without hydrazine, respectively, in a buffer solution $(0.1 \mathrm{~mol} / \mathrm{L})$ ) first increased and then slightly decreased. Thus, the total surface of the $\mathrm{Fe}_{3} \mathrm{O}_{4} \mathrm{NPs}$ appeared to be saturated with DPB within $5 \mathrm{~h}$, and additional time did not influence the amount of DPB self-assembled on the $\mathrm{Fe}_{3} \mathrm{O}_{4} \mathrm{NPs}$. Therefore, $5 \mathrm{~h}$ was selected as the optimal period for the self-assembly of DPB on the $\mathrm{Fe}_{3} \mathrm{O}_{4} \mathrm{NPs}$.

The effect of $\mathrm{pH}$ on the oxidation peak of hydrazine at the MBCPE/ $\mathrm{Fe}_{3} \mathrm{O}_{4} \mathrm{NPs} / \mathrm{DPB}$ electrode was investigated by cyclic voltammetry in buffer solution $(0.1 \mathrm{~mol} / \mathrm{L})$ at various $\mathrm{pH}$ from 2.0 to 12.0 . The $\mathrm{pH}$ was found to affects electrocatalytic oxidation of DPB in the presence of hydrazine. It can be seen in Fig. 5 (b) that $\Delta I$ increased from $\mathrm{pH}=2.0$ to 7.0 , and then decreased after $\mathrm{pH}=7.0$ (7.0-12.0). Therefore, $\mathrm{pH}=7.0$ was selected as the optimum $\mathrm{pH}$ for the following experiments.

\subsection{Effect of scan rate and Tafel plot}

The effect of scan rate on the electrocatalytic oxidation of hydrazine at MBCPE/ $\mathrm{Fe}_{3} \mathrm{O}_{4} \mathrm{NPs} / \mathrm{DPB}$ was investigated by cyclic voltammetry. Fig. 6(a) shows the cyclic voltammograms of $\mathrm{MBCPE} / \mathrm{Fe}_{3} \mathrm{O}_{4} \mathrm{NPs} / \mathrm{DPB}$ at various scan rates obtained in a phosphate buffer solution $(0.1 \mathrm{~mol} / \mathrm{L} ; \mathrm{pH}=7.0)$ containing hydrazine ( $4 \mu \mathrm{mol} / \mathrm{L})$. Fig. 6 (b) shows a selected region of the Tafel plot for the cyclic voltammogram obtained at a scan rate of $20 \mathrm{mV} / \mathrm{s}$. The hydrazine oxidation current was found to increase linearly with the square root of scan rate (Fig. 6(c)), indicating that the reaction was mass transfer controlled. Also, a plot of normalized current $\left(I_{\mathrm{p}} / v^{1 / 2}\right)$ versus sweep rate (Fig. 6(d)) revealed that increasing $v$ caused the normalized currents $\left(I_{\mathrm{p}} / \nu^{1 / 2}\right)$ to decrease until a certain level was reached.
This confirms that the oxidation of hydrazine at MBCPE/ $\mathrm{Fe}_{3} \mathrm{O}_{4} \mathrm{NPs} / \mathrm{DPB}$ had an EC' catalytic mechanism. Fig. 6(e) reveals the Tafel plot drawn from the data of the rising part of the plotted current-voltage curve obtained at a scan rate of 20 $\mathrm{mV} / \mathrm{s}$. The slope of the Tafel plot was calculated to be 0.204 $\mathrm{V} /$ decade. The charge transfer coefficient between hydrazine and MBCPE/ $\mathrm{Fe}_{3} \mathrm{O}_{4} \mathrm{NPs} / \mathrm{DPB}$ was calculated to be $\alpha=0.69$ using the slope of Tafel plot, the equation $2.3 R T / n_{\alpha}(1-\alpha) F$, and assuming $n_{\alpha}=1$.

\subsection{Chronoamperometric measurements}

The chronoamperometric behavior of $\mathrm{MBCPE} / \mathrm{Fe}_{3} \mathrm{O}_{4} \mathrm{NPs}$ in a phosphate buffer solution containing DPB was examined in the absence and presence of hydrazine. Chronoamperometric measurements of various concentrations of hydrazine solutions were carried out by setting the potential of working electrode at $250 \mathrm{mV}$ versus the $\mathrm{Ag} / \mathrm{AgCl}$ electrode [41]. The obtained chronoamperograms are depicted in Fig. 7(a). The diffusion coefficient of hydrazine was determined from the results. In the presence of hydrazine at an experimental time of 0-20 s, the modifier was oxidized and the rate of electrocatalyzed hydrazine oxidation increased with the diffusion of hydrazine from the bulk to the modifier on the electrode surface, thus increasing oxidation current. The diffusion coefficient $(D)$ of hydrazine can be evaluated using the Cottrell equation, which describes relationship between diffusion coefficient and the hydrazine bulk concentration $[42,43]$.

$$
I=n F A C(D / \pi t)^{1 / 2}
$$

where $D$ and $C$ are the diffusion coefficient $\left(\mathrm{cm}^{2} / \mathrm{s}\right)$ and the bulk concentration $\left(\mathrm{mol} / \mathrm{cm}^{3}\right)$ of hydrazine, respectively. $A$ is the effective electrode area $\left(A=0.52 \mathrm{~cm}^{2}\right)$ and $n$ is the number of electrons transferred $(n=4)$ in the oxidation reaction. Fig. 7(a) shows that the level of Cottrell current increased with the hydrazine concentration. Fig. 7(b) shows the plot of $I$ vs. $t^{-1 / 2}$. The slopes of the straight lines from the Fig. 7(b) are plotted versus hydrazine concentration in Fig. 7(c). From the slope of this line, the diffusion coefficient of hydrazine was calculated to be 7.19 $\times 10^{-6} \mathrm{~cm}^{2} / \mathrm{s}$, comparable with the previously reported values

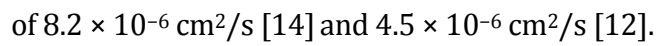



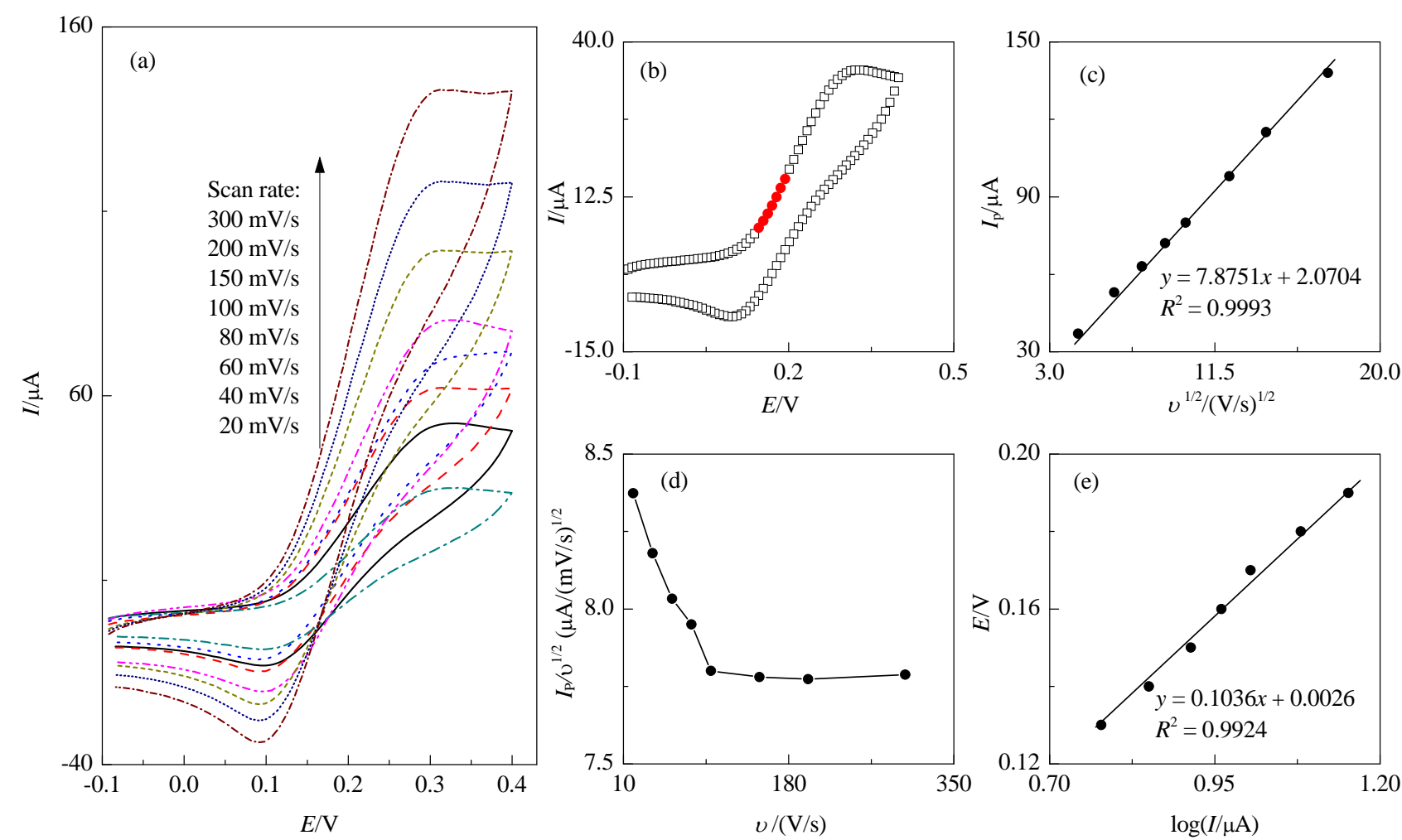

Fig. 6. (a) Cyclic votammograms of $\mathrm{MBCPE} / \mathrm{Fe}_{3} \mathrm{O}_{4} \mathrm{NPs} / \mathrm{DPB}$ in phosphate buffer $(0.1 \mathrm{~mol} / \mathrm{L} ; \mathrm{pH}=7.0)$ containing hydrazine $(4.0 \mu \mathrm{mol} / \mathrm{L})$ at different scan rates. The curves from down to up correspond to 20,40, 60, 80,100,150, 200 and $300 \mathrm{mV} / \mathrm{s}$ scan rates, respectively. (b) The selected region for plotting Tafel diagram in scan rate $20 \mathrm{mV} / \mathrm{s}$ for electrocatalytic oxidation of hydrazine at MBCPE/Fe $\mathrm{O}_{4} \mathrm{NPs} / \mathrm{DPB}$. (c) Variation of the electrocatalytic peak currents vs. $v^{1 / 2}$. (d) Variation of the scan rate-normalized peak current $\left(I_{\mathrm{p}} / v^{1 / 2}\right)$ versus scan rate $(v)$. (e) Tafel plot derived from the rising part of current potential curve recorded at scan rate of $20 \mathrm{mV} / \mathrm{s}$.
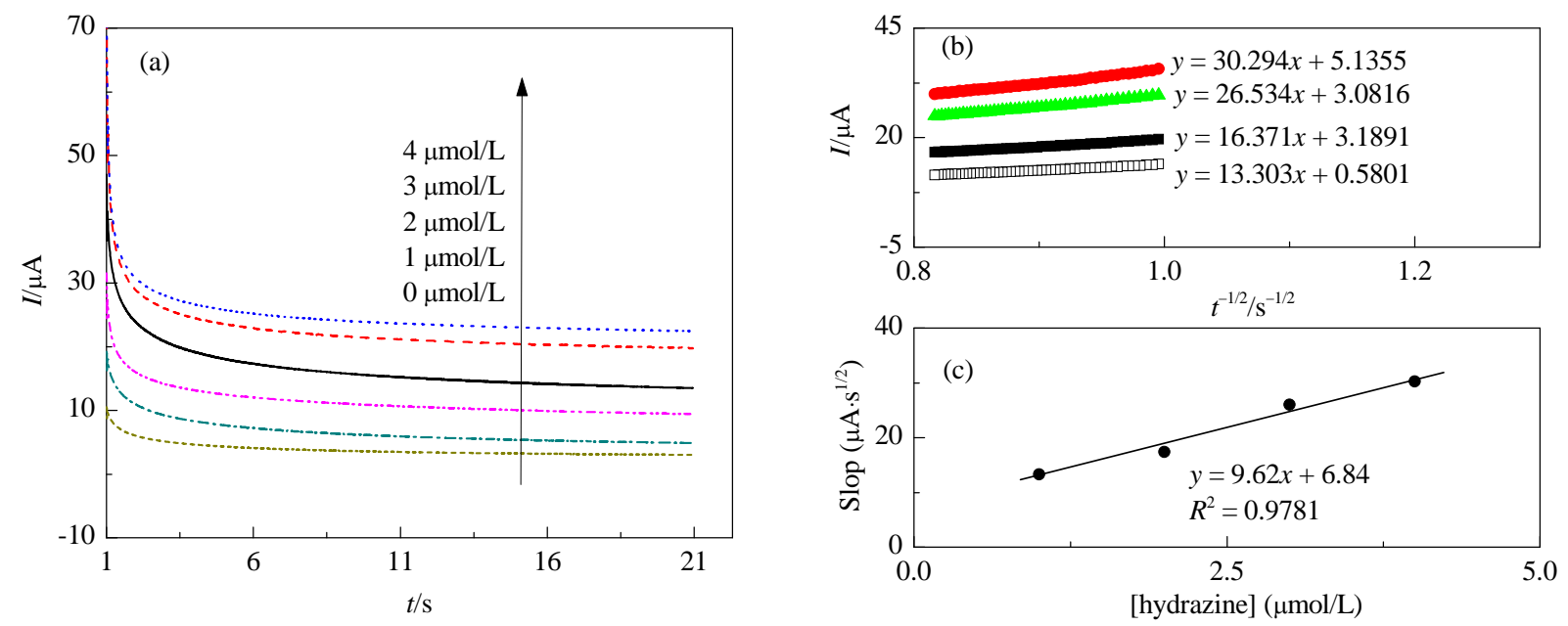

Fig. 7. (a) Chronoamperogrames of MBCPE/ $\mathrm{Fe}_{3} \mathrm{O}_{4} \mathrm{NPs} / \mathrm{DPB}$ in phosphate buffer solution ( $\left.0.1 \mathrm{~mol} / \mathrm{L}\right)$ containing $0,1,2,3$ and $4 \mu \mathrm{mol} / \mathrm{L}$ of hydrazine (from down to up). (b) Plot of $I$ vs. $t^{-1 / 2}$ obtained from chronoamperometric experiments. (c) The slopes of the resulting straight line of (b) vs. hydrazine concentration.

The chronoamperometric method was also applied to evaluate the catalytic rate constant, $k(\mathrm{~L} /(\mathrm{mol} \cdot \mathrm{s}))$, of the reaction between hydrazine and DPB using the Galus method [44].

$$
I_{c} / I_{1}=\gamma^{1 / 2}\left[\pi^{1 / 2} \operatorname{erf}\left(\gamma^{1 / 2}\right)+\exp (-\gamma) / \gamma^{1 / 2}\right] \quad \text { Eq. (2) }
$$

where $I_{c}$ is the catalytic current of DPB in the presence of hydrazine at MBCPE $/ \mathrm{Fe}_{3} \mathrm{O}_{4} \mathrm{NPs}, I_{1}$ is the limited current in the absence of hydrazine, and $\gamma=k C t$ (where $C$ is the bulk concentration of hydrazine) is the argument of the error function. In cases where $\gamma$ is more than 2 , the error function is almost equal to 1 and the above equation can be reduced to:

$$
I_{c} / I_{1}=\pi^{1 / 2}(k C t)^{1 / 2}
$$

where $k, C$, and $t$ are the catalytic rate constant $(\mathrm{L} /(\mathrm{mol} \cdot \mathrm{s}))$, catalyst concentration (mol/L), and time elapsed, respectively. $I_{\mathrm{c}}$ and $I_{l}$ are the currents of MBCPE/ $/ \mathrm{Fe}_{3} \mathrm{O}_{4} \mathrm{NPs} / \mathrm{DPB}$ in a buffer solution $(\mathrm{pH}=7.0)$ in the presence and absence of hydrazine, respectively. The values of $I_{c} / I_{1}$ versus $t^{1 / 2}$ were plotted, and 
from the slope of this plot, the average value of $k$ was calculated to be $5.1 \times 10^{3} \mathrm{~L} /(\mathrm{mol} \cdot \mathrm{s})$.

\subsection{Investigation of reaction mechanism}

The following processes are suggested for the mechanism of the electrocatalyzed hydrazine oxidation reaction. (1) Firstly, DPB is oxidized on the surface of MBCPE/ $\mathrm{Fe}_{3} \mathrm{O}_{4} \mathrm{NPs}$. (2) Electrocatalytic reaction between the oxidized form of DPB and hydrazine takes place on the surface of the electrode, increasing the anodic peak current. Fig. 8(a) shows cyclic voltammograms of $\mathrm{MBCPE} / \mathrm{Fe}_{3} \mathrm{O}_{4} \mathrm{NPs} / \mathrm{DPB}$ in the presence of different concentrations of hydrazine. With increasing hydrazine concentration, the oxidation peak current increased while the cathodic peak current decreased. These results confirm an electrocatalytic behavior for hydrazine oxidation on the surface of $\mathrm{MBCPE} / \mathrm{Fe}_{3} \mathrm{O}_{4} \mathrm{NPs} / \mathrm{DPB}$ via an EC' mechanism. This mechanism is shown in Fig. 8(b). Hydrazine is oxidized in the catalytic chemical reaction $\left(\mathrm{C}^{\prime}\right)$ by the oxidized form of DPB, which is produced via an electrochemical reaction (E). Hydrazine in aqueous solutions can be oxidized with the loss of four electrons and the production of nitrogen gas $[45,46]$.

\subsection{Differential pulse voltammetry investigations}

Differential pulse voltammetry (DPV) is the most widely applicable technique in electrochemistry owing to its high sensitivity and low charging current contribution to the background current, so this technique was used to determine the limit and the linear range of hydrazine detection at the present electrodes. The effect of hydrazine concentration on the DPV at the electrodes is presented in Fig. 9(a). As Figs. 9(b) and (c) show, the plot of peak current vs. hydrazine concentration exhibited

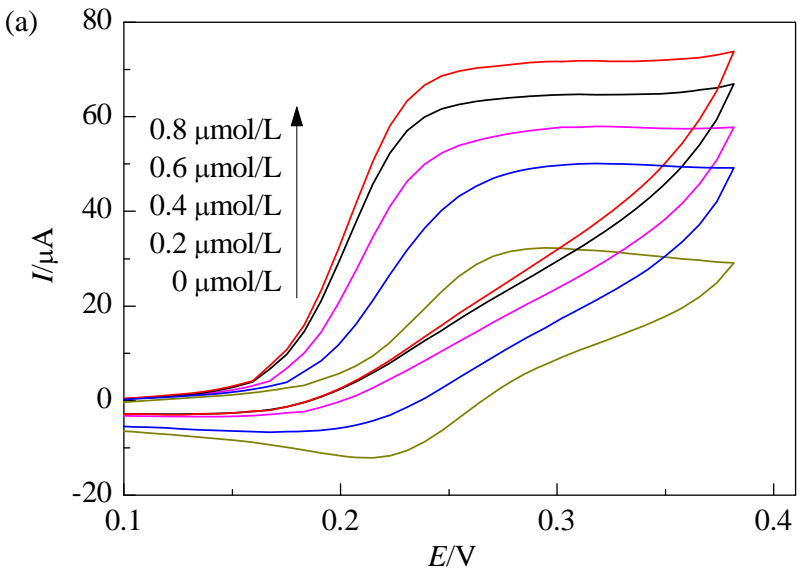

(b)

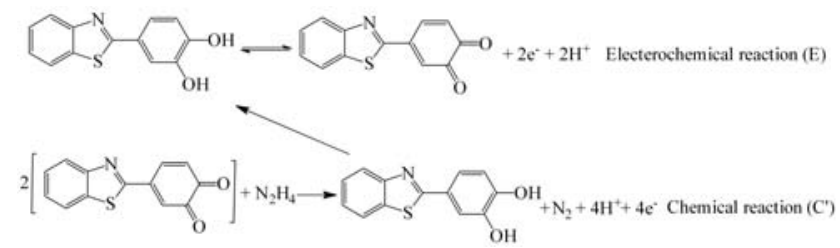

Fig. 8. (a) CVs of MBCPE/ $/ \mathrm{Fe}_{3} \mathrm{O}_{4} \mathrm{NPs} / \mathrm{DPB}$ in phosphate buffer solution $(0.1 \mathrm{~mol} / \mathrm{L} ; \mathrm{pH}=7.0)$ at scan rate $10 \mathrm{mV} / \mathrm{s}$ in $0,0.2,0.4,0.6$ and 0.8 $\mu \mathrm{mol} / \mathrm{L}$ hydrazine from bottom to top, respectively. (b) The electrocatalytic reaction mechanism for hydrazine on the surface of $\mathrm{MBCPE} / \mathrm{Fe}_{3} \mathrm{O}_{4} \mathrm{NPs} / \mathrm{DPB}$.

two linear ranges, the first $0.1-0.4 \mu \mathrm{mol} / \mathrm{L}$ with a correlation coefficient of 0.9995 and the second $0.7-12.0 \mu \mathrm{mol} / \mathrm{L}$ with a correlation coefficient of 0.9705 . Based on $3 \mathrm{~s} \mathrm{~b} / \mathrm{m}$ (where $s_{\mathrm{b}}$ is the standard deviation of a blank solution and $m$ is the slope of the calibration curve (Fig. 9(b)), the detection limit was deter-
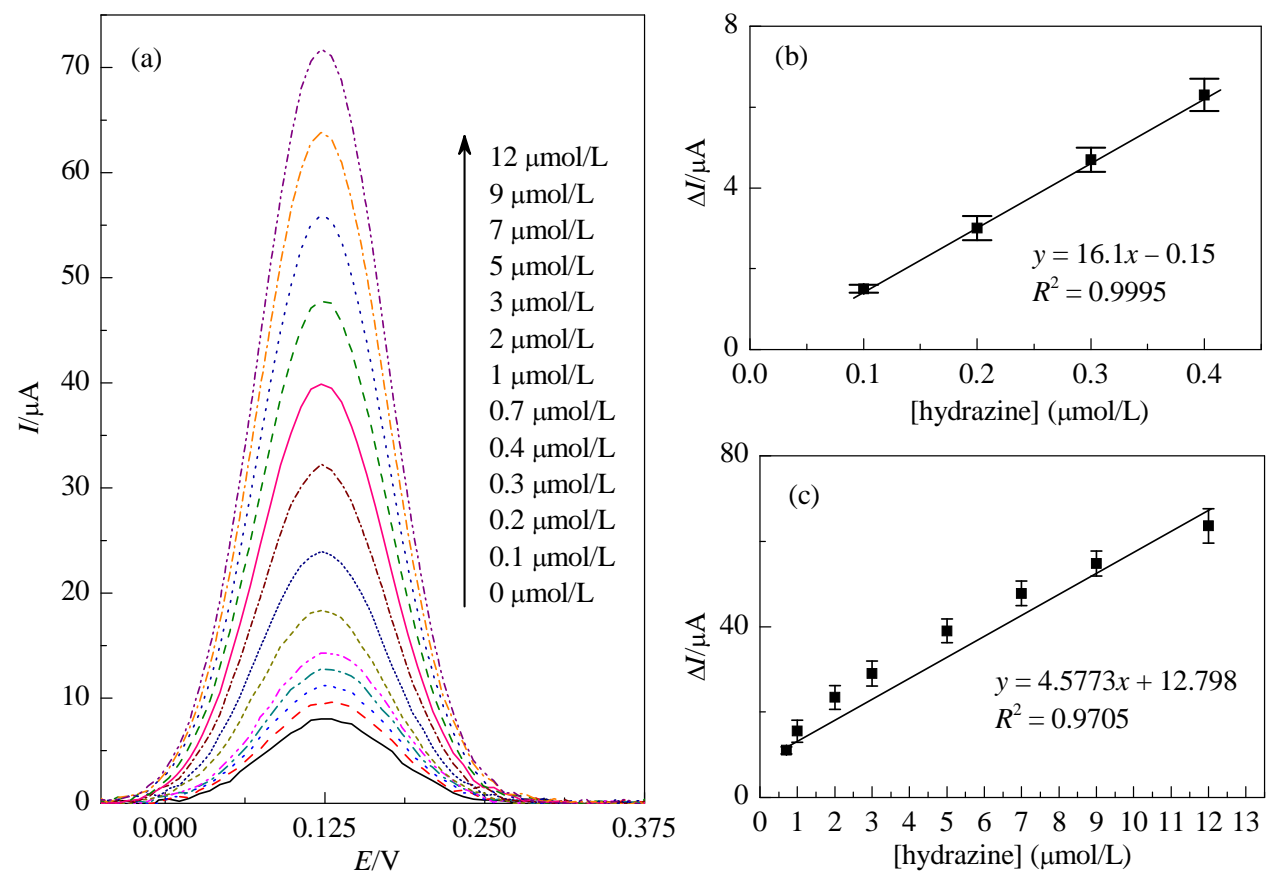

Fig. 9. (a) Differential pulse voltammograms of $\mathrm{MBCPE} / \mathrm{Fe}_{3} \mathrm{O}_{4} \mathrm{NPs} / \mathrm{DPB}$ in phosphate buffer solution $(0.1 \mathrm{~mol} / \mathrm{L}$; $\mathrm{pH}=7.0)$ containing different concentrations of hydrazine. (b) Calibration curve in the range of 0.1 to $0.4 \mu \mathrm{mol} / \mathrm{L}$. (c) Calibration curve in the range of 0.7 to $12.0 \mu \mathrm{mol} / \mathrm{L}$. 
mined to be $18.0 \mathrm{nmol} / \mathrm{L}$. The limit of detection, linear range, optimal pH for the catalytic effect, and peak potential shift of a number of previously reported modified electrodes against that of the proposed electrode for the determination of hydrazine are listed in Table $1[8,31,32,47-50]$. According to Table 1 , the detection limit of the proposed electrode sensor was lower than that of all other methods except for that of Ref. 48. The very low detection limit for determination of hydrazine obtained in this work arose from the presence of the magnetic bar in the CPE electrode, which caused the electrode surface to adsorb a large amount of $\mathrm{Fe}_{3} \mathrm{O}_{4} \mathrm{NPs} / \mathrm{DPB}$ and thereby greatly increased the effective area of the electrode.

\subsection{Effect of chemical interferents}

Several cations and anions including $\mathrm{Na}^{+}, \mathrm{Cs}^{+}, \mathrm{NH}_{4}{ }^{+}, \mathrm{Mg}^{2+}$, $\mathrm{Ca}^{2+}, \mathrm{Ba}^{2+}, \mathrm{Cd}^{2+}, \mathrm{Zn}^{2+}, \mathrm{Pb}^{2+}, \mathrm{Mn}^{2+}, \mathrm{Cu}^{2+}, \mathrm{C}_{2} \mathrm{O}_{4}{ }^{2-}, \mathrm{NO}_{3}{ }^{-}, \mathrm{CH}_{3} \mathrm{COO}^{-}$, $\mathrm{Br}^{-}, \mathrm{F}^{-}, \mathrm{I}^{-}$were checked for interference with the hydrazine oxidation reaction. To investigate the effect of these interferents, the concentration of hydrazine was set to $1.0 \mu \mathrm{mol} / \mathrm{L}$ under optimum conditions. Up to a molar ratio of 1000 , none of the investigated anions and cations had any interference effect on the hydrazine oxidation peak current. The checking of compounds such as hydroxylamine that may be present in water matrix was also carried out, and it was found that hydroxylamine had a serious interference effect.

\subsection{Simultaneous determination of hydrazine and phenol}

Hydrazine and phenol are two important hazardous compounds that exist together in water samples. Owing to small difference between the oxidation potentials of hydrazine and phenol, the simultaneous determination of these two components using electrochemical methods is difficult but vital. In this work, the simultaneous determination of hydrazine and phenol was successfully achieved using the proposed chemically modified $\left(\mathrm{Fe}_{3} \mathrm{O}_{4} \mathrm{NPs} / \mathrm{DPB}\right)$ electrochemical sensors.

DPV was used for the simultaneous determination of hydrazine and phenol at MBCPE/ $\mathrm{Fe}_{3} \mathrm{O}_{4} \mathrm{NPs} / \mathrm{DPB}$, because of the better selectivity and lower detection limit of this technique compared with those of other electrochemical methods. At first, the intermolecular interaction between the two compounds was investigated at $\mathrm{MBCPE} / \mathrm{Fe}_{3} \mathrm{O}_{4} \mathrm{NPs} / \mathrm{DPB}$ and then the concentra- tion of phenol was varied while the hydrazine concentration was kept constant. A hydrazine concentration of $0.3 \mu \mathrm{mol} / \mathrm{L}$, the peak current of phenol oxidation was proportional to its concentration from 100-470.0 $\mu \mathrm{mol} / \mathrm{L}\left(\Delta I(\mu \mathrm{A})=0.0061 C_{\text {phenol }}\right.$ $(\mu \mathrm{mol} / \mathrm{L})+0.655$ and $\left.R^{2}=0.98\right)$ and there was no change in the peak current of hydrazine. Therefore, increasing the concentration of phenol did not affect the hydrazine peak current (Figure not shown). Similar experiments showed that increasing the concentration of hydrazine $\left(\Delta I(\mu \mathrm{A})=4.38 C_{\text {hydrazine }}(\mu \mathrm{mol} / \mathrm{L})+\right.$ 11.44 and $R^{2}=0.975$ ) did not affect the peak current of phenol at the MBCPE/ $\mathrm{Fe}_{3} \mathrm{O}_{4} \mathrm{NPs} / \mathrm{DPB}$ electrode. Thus, the two analytes did not exhibit any intermolecular interaction and simultaneous determination of these two analytes without interference was possible at $\mathrm{MBCPE} / \mathrm{Fe}_{3} \mathrm{O}_{4} \mathrm{NPs} / \mathrm{DPB}$ sensor. Differential pulse voltammograms obtained for different concentrations of hydrazine and phenol are plotted in Fig. 10(a). The oxidation peak currents of hydrazine and phenol increased with their respective concentrations. Figs. 10 (b) and (c) exhibit the dependence of the peak current on the concentration of hydrazine $\left(\Delta I(\mu \mathrm{A})=4.407 C_{\text {hydrazine }}(\mu \mathrm{mol} / \mathrm{L})+12.45, R^{2}=0.972\right.$ and $\Delta I$ $\left.(\mu \mathrm{A})=16.5 C_{\text {hydrazine }}(\mu \mathrm{mol} / \mathrm{L})-1.55, R^{2}=0.985\right)$ and phenol $(\Delta I$ $\left.(\mu \mathrm{A})=0.0062 C_{\text {phenol }}(\mu \mathrm{mol} / \mathrm{L})+8.74, R^{2}=0.991\right)$, respectively. It is notable that the sensitivity of the modified electrode to hydrazine was approximately the same in the absence and presence of phenol, which indicates that the oxidation of hydrazine and phenol at $\mathrm{MBCPE} / \mathrm{Fe}_{3} \mathrm{O}_{4} \mathrm{NPs} / \mathrm{DPB}$ were independent processes. From the calibration graph (Fig. 10), the lower detection limit of phenol $(3 \mathrm{sb} / \mathrm{m})$ was found to be $24.3 \mu \mathrm{mol} / \mathrm{L}$.

\subsection{Repeatability and stability of the sensor}

For repeatability investigations of the fabricated hydrazine sensor, three parallel MBCPE/ $\mathrm{Fe}_{3} \mathrm{O}_{4} \mathrm{NPs} / \mathrm{DPB}$ sensors were constructed and then examined using hydrazine $(4 \mu \mathrm{mol} / \mathrm{L})$. The three independent hydrazine sensors were produced on the same day and all solutions used, such as the $\mathrm{Fe}_{3} \mathrm{O}_{4} \mathrm{NPs}$ and DPB suspensions, were identical. An acceptable relative standard deviation of 3.8\% $(n=3)$ was obtained for $\Delta I$ (where $\Delta I=$ $I_{\text {final }}-I_{\text {initial }}$ and $I_{\text {final }}$ and $I_{\text {initial }}$ are DPB peak currents in buffer solution $(0.1 \mathrm{~mol} / \mathrm{L})$ at $\mathrm{pH}=7.0$ with and without hydrazine, respectively), indicating that this electrochemical sensor (MBCPE/ $\mathrm{Fe}_{3} \mathrm{O}_{4} \mathrm{NPs} / \mathrm{DPB}$ ) had a satisfactory repeatability. The stability of the proposed modified electrode was also investi-

Table 1

Comparison of the efficiency of some modified electrodes used for determination of hydrazine.

\begin{tabular}{|c|c|c|c|c|c|c|}
\hline Method & Electrode & Peak potential shift $(\mathrm{mV})$ & $\mathrm{pH}$ & Dynamic range $(\mu \mathrm{mol} / \mathrm{L})$ & Detection limit $(\mu \mathrm{mol} / \mathrm{L})$ & Ref. \\
\hline$\overline{A m p}$ & $\mathrm{WO}_{3}$ & 700 & 7.0 & $100-1000$ & 144 & [8] \\
\hline $\mathrm{CV}$ & $\mathrm{PANI} / \mathrm{Pd}_{0}$ & - & 7.0 & $0.3-12000$ & 0.05 & [31] \\
\hline $\mathrm{CV}$ & PEDOP/MWCNT-Pd & - & 7.4 & $0.1-5000$ & 0.04 & {$[32]$} \\
\hline DPV & $p$-APMWCNTPE & 600 & 7.0 & $0.5-175$ & 0.3 & [47] \\
\hline Amp & AG/Au-NPs & 400 & 7.0 & $0.002-936$ & 0.00057 & [48] \\
\hline DPV & BFT-CNT-GCE & 170 & 8.0 & $0.5-700.0$ & 0.033 & [49] \\
\hline DPV & Co(II)BBAEDI-MWCNT-CPE & 500 & 7.0 & $0.3-70$ & 0.1 & [50] \\
\hline DPV & $\mathrm{MBCPE} / \mathrm{Fe}_{3} \mathrm{O}_{4} / \mathrm{DPB}$ & 550 & 7.0 & $0.1-12$ & 0.018 & This work \\
\hline
\end{tabular}

$\mathrm{CV}=$ Cyclic voltammetry; DPV = Differential pulse voltammetry; Amp = Amperometry; $p$-APMWCNTPE = $p$-Aminophenol-multiwall carbon nanotube-paste electrode; BFT = 1-Benzyl-4-ferrocenyl-1H-[1,2,3]-triazole; $\mathrm{PEDOP}=$ Poly-ethylendioxy pyrrole; $\mathrm{CNT}=\mathrm{Carbon}$ Nano tube; $\mathrm{CPE}=\mathrm{Carbon}$ paste electrode; $\mathrm{AG}=$ Activated graphite. 

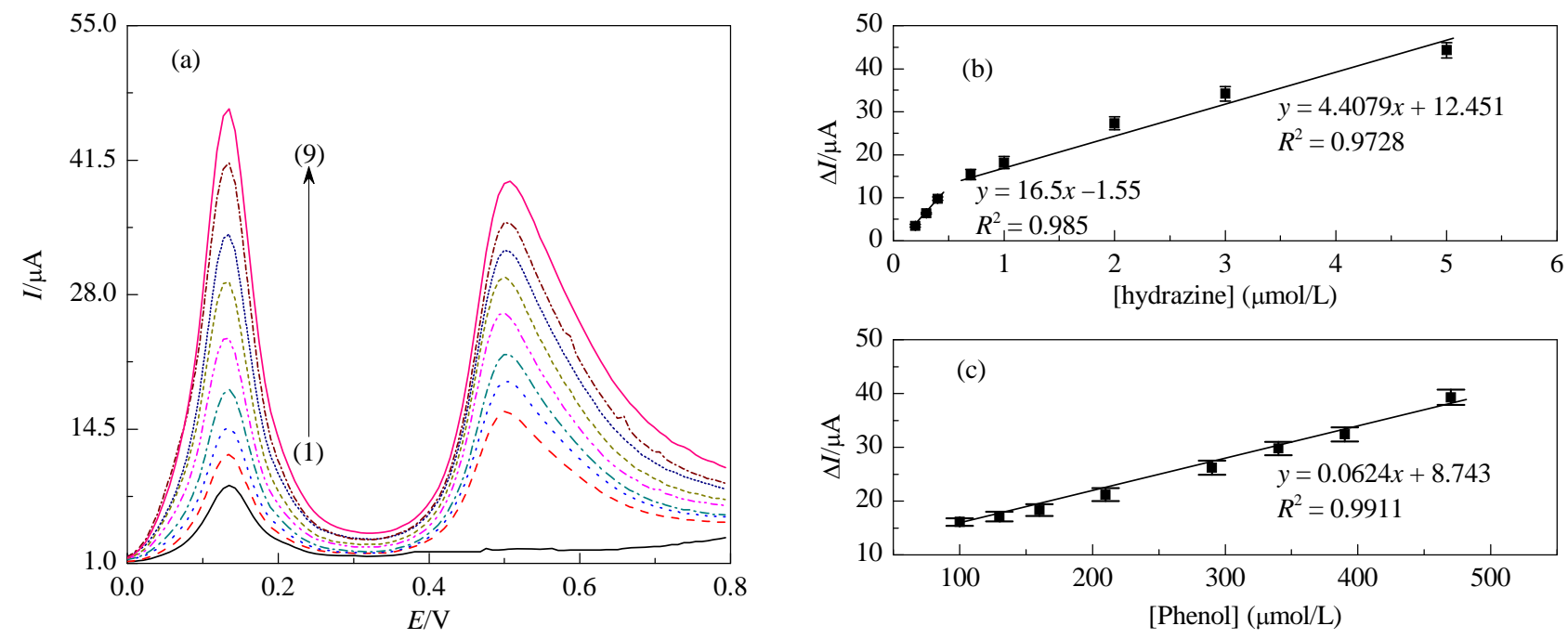

Fig. 10. (a) Differential pulse voltammograms of $\mathrm{MBCPE} / \mathrm{Fe}_{3} \mathrm{O}_{4} \mathrm{NPs} / \mathrm{DPB}$ in phosphate buffer solution $(0.1 \mathrm{~mol} / \mathrm{L}$; $\mathrm{pH}=7.0)$ containing different concentrations of hydrazine and phenol. (1)-(9) Mixed solutions of $0.2+100,0.3+130,0.4+160,0.7+210,1+290,2+340,3+390$, and 5+420 respectively, in which the values are the concentrations of hydrazine and phenol in $\mu \mathrm{mol} / \mathrm{L}$. (b) Plot of the peak currents as a function of hydrazine concentration (in the linear range of $0.2-5 \mu \mathrm{mol} / \mathrm{L}$ of hydrazine). (c) Plot of the peak currents as a function of phenol concentration of $100-470 \mu \mathrm{mol} / \mathrm{L}$.

gated. After storage of the modified electrode in phosphate buffer solution $(0.1 \mathrm{~mol} / \mathrm{L} ; \mathrm{pH}=7.0)$ at $25{ }^{\circ} \mathrm{C}$ for $4 \mathrm{~d}$, the response of electrode retained about $94 \%$ of its primary response, a suitable stability.

\subsection{Application of the hydrazine sensor}

As explained, hydrazine in the environment poses some risks to human life. Although the determination of hydrazine with the designed MBCPE/ $\mathrm{Fe}_{3} \mathrm{O}_{4} \mathrm{NPs} / \mathrm{DPB}$ sensor was found to be applicable under laboratory conditions, an attempt was made to assess the practical analytical performance of the method with water samples. Five solutions containing appropriate amounts of hydrazine were prepared and analyzed by the proposed method. According to Table 2, an average recovery of $99 \%$ was obtained, which indicates that the typical constituents of water did not significantly interfere with the determination of hydrazine.

To ensure the accuracy of this method for the practical measurement of hydrazine, the hydrazine concentration of auxiliary cooling water from Yazd Power Generation Company

Table 2

Determination of hydrazine in water samples using proposed sensor $(n=5)$.

\begin{tabular}{lccc}
\hline Sample & $\begin{array}{c}\text { Hydrazine added } \\
(\mu \mathrm{mol} / \mathrm{L})\end{array}$ & $\begin{array}{c}\text { Hydrazine found } \\
(\mu \mathrm{mol} / \mathrm{L})\end{array}$ & Recovery $(\%)$ \\
\hline Drinking water & - & $<$ Detection limit & - \\
Drinking water & 1 & $1.03( \pm 0.08)$ & 101 \\
Drinking water & 3 & $3.0( \pm 0.2)$ & 100 \\
Drinking water & 6 & $6.1( \pm 0.5)$ & 101 \\
River water* & 9 & $8.9( \pm 0.2)$ & 98 \\
River water* & 10 & $10.5( \pm 0.1)$ & 104 \\
River water* & 12 & $12( \pm 0.2)$ & 100 \\
\hline
\end{tabular}

*Zayandeh-Rood in Isfahan city. was analyzed by the proposed method, and the results were compared with those obtained using a spectrophotometric method. The hydrazine concentration of the water sample was found to be $150.2( \pm 3.8) \mathrm{ppb}(n=4)$ using the proposed method and $146.8( \pm 3.1)$ ppb $(n=4)$ using the selected spectrophotometric method [51], respectively. A $t$-test [52] was carried out and $t_{\exp }$ was found to be 1.42, which is less than the critical $t$ (2.45) within a $95 \%$ confidence level. The $t$-test data show that there was no systematic error between the results obtained by the two methods. Therefore, the present electrochemical method seems to be promising for the determination of hydrazine in water samples. The standard addition method was also used to determine hydrazine and phenol concentrations in water samples by DPV. The obtained results are provided in Table 3. The recovery percentages in this table show that the proposed sensor (MBCPE/ $\mathrm{Fe}_{3} \mathrm{O}_{4} \mathrm{NPs} / \mathrm{DPB}$ ) is applicable for the simultaneous determination of hydrazine and phenol in real water samples.

\section{Table 3}

Determination of hydrazine and phenol in water sample using proposed sensor $(n=5)$.

\begin{tabular}{lccc}
\hline Sample & Added $(\mu \mathrm{mol} / \mathrm{L})$ & Found $(\mu \mathrm{mol} / \mathrm{L})$ & Recovery $(\%)$ \\
\hline Hydrazine & 0.00 & - & - \\
& 0.20 & 0.19 & 95 \\
& 0.30 & 0.31 & 103 \\
& 0.40 & 0.41 & 102 \\
& 0.70 & 0.69 & 98 \\
Phenol & 1.00 & 1.05 & 105 \\
& 0.00 & - & - \\
& 100 & 103 & 103 \\
& 130 & 129 & 99 \\
& 160 & 162 & 101 \\
& 210 & 208 & 99 \\
\hline
\end{tabular}




\section{Conclusions}

In the present study, robust new magnetic bar carbon paste electrode modified with $\mathrm{Fe}_{3} \mathrm{O}_{4} \mathrm{NPs} / \mathrm{DPB}$ was constructed as an electrochemical sensor for determination of hydrazine. The electrochemical oxidation of hydrazine at the proposed electrode was studied by cyclic voltammetry, differential pulse voltammetry, and chronoamperometry. Compared with the response observed for unmodified MBCPE, the electrochemical sensitivity of hydrazine at the modified electrode $\mathrm{MBCPE} / \mathrm{Fe}_{3} \mathrm{O}_{4} \mathrm{NPs} / \mathrm{DPB}$ was dramatically improved. Therefore, and owing to its unique structure, the fabricated sensor (MBCPE/ $\mathrm{Fe}_{3} \mathrm{O}_{4} \mathrm{NPs} / \mathrm{DPB}$ ) has a number of advantages over the non-modified electrode (MBCPE), including as high conductivity and fast electron transfer. Briefly, kinetic parameters such as the diffusion coefficient and the electron transfer coefficient of hydrazine were determined by electrochemical methods under optimum conditions. The results obtained were comparable with those reported in the literature for similar approaches. The method was also successfully used for the determination of hydrazine in water samples. The fabricated sensor was very rapid, reproducible, stable, selective, and sensitive for determination of hydrazine. Generally, this electrochemical sensor is capable of simultaneous determination of hydrazine and phenol in water samples. The present work may lead to the fabrication of new electrochemical sensors based on the application of nano-materials and modifiers to various electrode surfaces for the determination of different compounds, especially toxic species.

\section{Acknowledgments}

We gratefully acknowledge the support of this work by Yazd University research council.

\section{References}

[1] M. Revenga-Parra, E. Lorenzo, F. Pariente, Sens. Actuators B, 2005, 107, 678-687.

[2] E. H. Vernot, J. D. MacEwen, R. H. Bruner, C. C. Haun, E. R. Kinkead, D. E. Prentice, A. Hall 3rd, R. E. Schmidt, R. L. Eason, G. B. Hubbard, Fundam. Appl. Toxicol., 1985, 5, 1050-1064.

[3] J. M. Pingarron, I. O. Hernandez, A. Gonzalez-Cores, P. YanezSeudeno, Anal. Chim. Acta, 2001, 439, 281-290.

[4] M. Yang, H. L. Li, Talanta, 2001, 55, 479-484.

[5] P. Ortega-Barrales, A. Molina-Díaz, M. I. Pascual-Reguera, L. F. Capitán-Vallvey, Anal. Chim. Acta, 1997, 353, 115-122.

[6] A. Safavi, M. Tohidi, Anal. Methods, 2012, 4, 2233-2241.

[7] Q. F. Yi, W. Q. Yu, J. Electroanal. Chem., 2009, 633, 159-164.

[8] S. Shukla, S. Chaudhary, A. Umar, G. R. Chaudhary, S. K. Mehta, Sens. Actuators B, 2014, 196, 231-237.

[9] H. I. Seifart, W. L. Gent, D. P. Parkin, P. P. Jaarsveld, P. R. Donald, J. Chromatogr. B, 1995, 674, 269-275.

[10] M. Mori, K. Tanaka, Q. Xu, M. Ikedo, H. Taoda, W. Z. Hu, J. Chromatogr. A, 2004, 1039, 135-139.

[11] A. Safavi, M. A. Karimi, Talanta, 2002, 58, 785-792.

[12] H. Karimi-Maleh, P. Biparva, M. Hatami, Biosens. Bioelectron., 2013, 48, 270-275.

[13] H. Karimi-Maleh, F. Tahernejad-Javazmi, A. A. Ensafi, R. Moradi, S. Mallakpour, H. Beitollahi, Biosens. Bioelectron., 2014, 60, 1-7.

[14] S. M. Golabi, H. R. Zare, J. Electroanal. Chem., 1999, 465, 168-176.

[15] M. Windholz, S. Budavari, L. Y. Stroumtsos, M. N. Fertig, The Merck Index, An Encyclopedia of Chemicals and Drugs, Merck \& Co., 1976.

[16] S. Korkut, B. Keskinler, E. Erhan, Talanta, 2008, 76, 1147-1152.

[17] A. A. Ensafi, E. Heydari-Bafrooei, B. Rezaei, Chin. J. Catal., 2013, 34, 1768-1775.

[18] A. Brega, P. Prandini, C. Amaglio, E. Pafumi, J. Chromatogr. A, 1990, 535, 311-316.

[19] K. D. Khalaf, B. A. Hasan, A. Morales-Rubio, M. de la Guardia, Talanta, 1994, 41, 547-556.

[20] L. Campanella, T. Beone, M. P. Sammartino, M. Tomassetti, Analyst,

\section{Graphical Abstract}

Chin. J. Catal., 2016, 37: 549-560 doi: 10.1016/S1872-2067(15)61046-4

Electrocatalytic oxidation of hydrazine on magnetic bar carbon paste electrode modified with benzothiazole and iron oxide nanoparticles: Simultaneous determination of hydrazine and phenol

Ali Benvidi*, Shahriar Jahanbani, Bibi-Fatemeh Mirjalili, Reza Zare

Yazd University, Iran

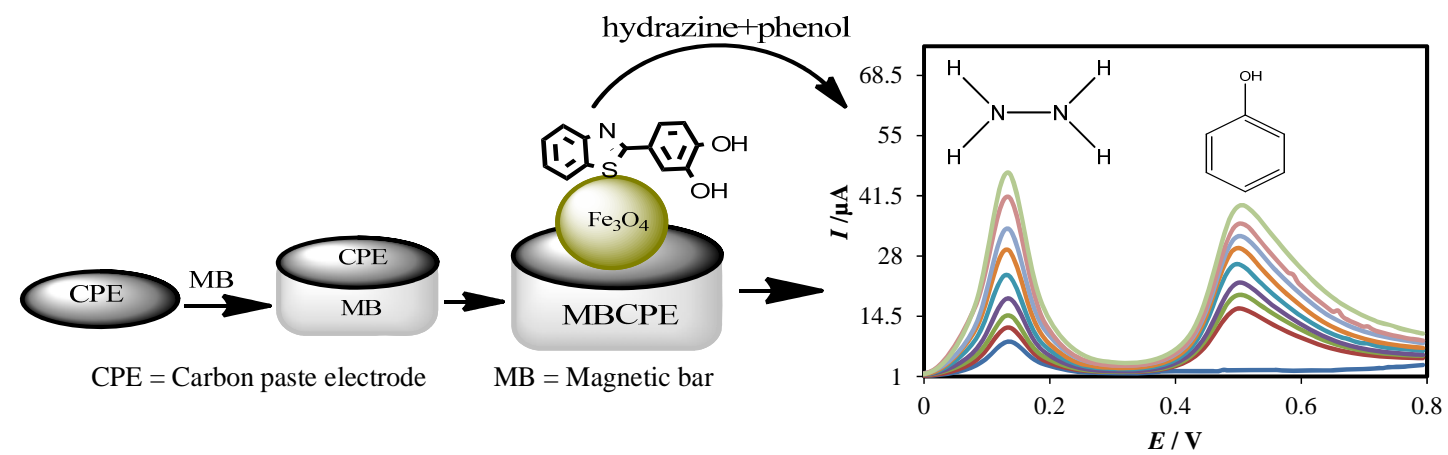

To prepare MBCPE/ $\mathrm{Fe}_{3} \mathrm{O}_{4} \mathrm{NPs} / \mathrm{DPB}$ sensor, a MBCPE was fabricated and then $\mathrm{Fe}_{3} \mathrm{O}_{4} \mathrm{NPs} / \mathrm{DPB}$ absorbed at the electrode surface for simultaneous determination of hydrazine and phenol. 
1993, 118, 979-986.

[21] H. Karimi-Maleh, M. Moazampour, A. A. Ensafi, S. Mallakpour, M. Hatami, Environ. Sci. Pollut. Res., 2014, 21, 5879-5888.

[22] G. Bayramoğlu, M. Y. Arica, Chem. Eng. J., 2008, 139, 20-28.

[23] X. S. Tang, D. Zhang, T. S. Zhou, D. X. Nie, Q. Y. Yang, L. T. Jin, G. Y. Shi, Anal. Methods, 2011, 3, 2313-2321.

[24] R. S. Sista, A. E. Eckhardt, V. Srinivasan, M. G. Pollack, S. Palanki, V. K. Pamula, Lab Chip, 2008, 8, 2188-2196.

[25] D. F. Cao, P. L. He, N. F. Hu, Analyst, 2003, 128, 1268-1274.

[26] H. Teymourian, A. Salimi, S. Khezrian, Biosens. Bioelectron., 2013, 49, 1-8.

[27] M. Arvand, M. Hassannezhad, Mater. Sci. Eng. C, 2014, 36, 160-167.

[28] E. Paleček, M. Fojta, Talanta, 2007, 74, 276-290.

[29] Y. Q. Zhao, H. Q. Luo, N. B. Li, Sens. Actuators B, 2009, 137, 722-726.

[30] D. Zhu, W. Li, H. M. Wen, J. R. Zhang, J. J. Zhu, Anal. Methods, 2013 5, 4321-4324.

[31] H. L. Lin, J. M. Yang, J. Y. Liu, Y. F. Huang, J. L. Xiao, X. Zhang, Electrochim. Acta, 2013, 90, 382-392.

[32] S. K. Kim, Y. N. Jeong, M. S. Ahmed, J. M. You, H. C. Choi, S. Jeon, Sens. Actuators B, 2011, 153, 246-251.

[33] A. Benvidi, S. Jahanbani, A. Akbari, H. R. Zare, J. Electroanal. Chem., 2015, 758, 68-77.

[34] J. Wang, A. N. Kawde, Electrochem. Commun., 2002, 4, 349-352.

[35] M. Mazloum-Ardakani, A. Dehghani-Firouzabadi, M. A. SheikhMohseni, A. Benvidi, B. B. F. Mirjalili, R. Zare, Measurement, 2015, 62, 88-96.

[36] A. K. Gupta, M. Gupta, Biomaterials, 2005, 26, 3995-4021.

[37] G. H. Du, Z. L. Liu, X. Xia, Q. Chu, S. M. Zhang, J. Sol-Gel Sci. Technol.,
2006, 39, 285-291.

[38] H. L. Zhu, E. Z. Zhu, G. F. Ou, L. H. Gao, J. J. Chen, Nanoscale Res. Lett,, 2010, 5, 1755-1761.

[39] I. S. Irgibaeva, D. A. Birimzhanova, N. N. Barashkov, Int. J. Quantum Chem., 2008, 108, 2700-2710.

[40] F. Xiao, C. P. Ruan, L. H. Liu, R. Yan, F. Q. Zhao, B. Z. Zeng, Sens. Actuators B, 2008, 134, 895-901.

[41] A. J. Bard, L. R. Faulkner, Electerochemical Methods: Fundamentals and Applications, 2nd Ed., John wiley, New York, 2001.

[42] K. B. Oldham, J. Electroanal. Chem. Interf. Electrochem., 1979, 105, 373-375.

[43] H. Razmi, A. Azadbakht, M. H. Sadr, Anal. Sci., 2005, 21, 1317-1323.

[44] Z. Galus, Fundamentals of Electerochemical Analysis, Ellis Harwood Press, New York, 1976.

[45] X. Q. Cao, B. C. Wang, Q. Su, J. Electroanal. Chem, 1993, 361, 211-214.

[46] J. Heitbaum, W. Vielstich, Electrochim. Acta, 1973, 18, 967-974.

[47] A. A. Ensafi, M. Lotfi, H. Karimi-Maleh, Chin. J. Catal., 2012, 33, 487-493.

[48] C. Karuppiah, S. Palanisamy, S. M. Chen, S. K. Ramaraj, P. Periakaruppan, Electrochim. Acta, 2014, 139, 157-164.

[49] H. Beitollahi, S. Tajik, H. Karimi-Maleh, R. Hosseinzadeh, Appl. Organomet. Chem., 2013, 27, 444-450.

[50] A. Benvidi, P. Kakoolaki, H. R. Zare, R. Vafazadeh, Electrochim. Acta, 2011, 56, 2045-2050.

[51] ASTM D1385-01, Standard Test Method for Hydrazine in Water, ASTM International, 2001.

[52] J. C. Miller, J. N. Miller, Statistics for Analytical Chemistry, 2nd Ed., John Wiley, New York, 1988.

\title{
苯并噻唑和铁氧化物纳米粒子修饰的磁性棒碳糊电极上肼的 电催化氧化反应: 同时检测肼和苯酚
}

\author{
Ali Benvidi*, Shahriar Jahanbani, Bibi-Fatemeh Mirjalili, Reza Zare \\ 亚兹德大学化学系, 亚兹德, 伊朗
}

摘要: 开发了一种磁性 $\mathrm{Fe}_{3} \mathrm{O}_{4}$ 纳米粒子和2-(3,4-二羟苯基)苯并噻唑(DPB)修饰的磁性棒碳糊电极(MBCPE)用于电化学检测 肼. 首先将DPB自组装在 $\mathrm{Fe}_{3} \mathrm{O}_{4}$ 纳米粒子上, 然后将此复合物吸附于设计的MBCPE上. MBCPE电极将磁性纳米粒子吸引到 电极表面. 所得新型电极具有高的导电性和大的有效比表面积, 因而对肼的电催化氧化反应有非常大的电流响应. 采用伏 安法、扫描电镜、电化学阻抗谱、红外光谱和紫外-可见光谱对修饰电极进行了表征. 采用伏安法研究了在磷酸盐缓冲溶 液 $(\mathrm{pH}=7.0)$ 中 $\mathrm{MBCPE} / \mathrm{Fe}_{3} \mathrm{O}_{4} \mathrm{NPs} / \mathrm{DPB}$ 电极上肼的电化学行为. 作为电化学传感器, $\mathrm{MBCPE} / \mathrm{Fe}_{3} \mathrm{O}_{4} \mathrm{NPs} / \mathrm{DPB}$ 电极对肼氧化 反应表现出极高的电催化活性. 在DPB存在下, 肼的氧化电势下降, 但其催化电流增加. 电催化电流与肼浓度在0.1-0.4和 0.7-12.0 $\mu \mathrm{mol} / \mathrm{L}$ 二个区间内表现出线性关系, 检测限为 $18.0 \mathrm{nmol} / \mathrm{L}$. 另外, 研究了 $\mathrm{MBCPE} / \mathrm{Fe}_{3} \mathrm{O}_{4} \mathrm{NPs} / \mathrm{DPB}$ 电极同时检测肼 和苯酚的性能. 伏安实验结果显示, 苯酚的线性区域为 $100-470 \mu \mathrm{mol} / \mathrm{L}$, 检测限为 $24.3 \mu \mathrm{mol} / \mathrm{L}$. 采用此电极检测了水样品 中的肼和苯酚.

关键词: 修饰电极; 电催化氧化; 肼; 苯酚; 磁性棒修饰碳糊电极; 四氧化三铁纳米粒子

收稿日期: 2015-11-01. 接受日期: 2016-01-16. 出版日期: 2016-04-05.

*通讯联系人. 电话: +98-353-8122645; 传真: +98-353-8210644; 电子信箱: abenvidi@yazd.ac.ir, benvidi89@gmail.com

本文的英文电子版由Elsevier出版社在ScienceDirect上出版(http://www.sciencedirect.com/science/journal/18722067). 